\title{
Performance of the WRF model with different physical parameterizations in the precipitation simulation of the state of Puebla
}

\author{
Indalecio MENDOZA URIBE ${ }^{1 *}$ and Diosey Ramón LUGO MORÍN² \\ ${ }^{1}$ Subcoordinación de Hidrometeorología, Instituto Mexicano de Tecnología del Agua, Paseo Cuauhnáhuac 8532, Col. \\ Progreso, 62550 Jiutepec, Morelos, México. \\ ${ }^{2}$ Universidad Intercultural del Estado de Puebla, Calle Principal a Lipuntahuaca s/n, Col. Lipuntahuaca, 73475 \\ Huehuetla, Puebla, México. \\ *Corresponding author; email: indalecio_mendoza@tlaloc.imta.mx
}

Received: November 15, 2018; accepted: January 24, 2020

\begin{abstract}
RESUMEN
En México, las intensas lluvias generadas por ciclones tropicales, frentes fríos y sistemas convectivos de mesoescala pueden causar inundaciones y deslaves, los cuales provocan daños a los sectores sociales, de servicios, económicos y financieros, entre otros, y dejan a la población con menos recursos y en mayor vulnerabilidad. Dado este escenario, el tema de la prevención de desastres tiene relevancia en la agenda de protección civil, en la cual se reconoce que es indispensable establecer estrategias y programas de largo alcance enfocados a prevenir y reducir sus efectos y no sólo prestar atención a las emergencias y desastres. El objetivo de este trabajo es evaluar el desempeño del modelo WRF para simular la precipitación pluvial acumulada en 24 horas en el estado de Puebla, considerando 768 combinaciones diferentes de parámetros físicos, en comparación con los registros de lluvia de estaciones climatológicas para el periodo del 1 de junio al 20 de agosto de 2017. Además, como parte de la investigación, se definieron las configuraciones óptimas para obtener el mejor rendimiento del modelo a nivel local y estatal.
\end{abstract}

\begin{abstract}
In Mexico, intense rains generated by tropical cyclones, cold fronts, and mesoscale convective systems can cause floods and landslides, causing damage to social, service, economic and financial sectors, among others, leaving the population with fewer resources and in greater vulnerability. Given this scenario, disaster prevention has relevance in the civil protection agenda, which recognizes that it is essential to establish longrange strategies and programs focused on preventing and reducing their effects, beyond only paying attention to emergencies and disasters. The objective of this work is to evaluate the performance of the WRF model for the simulation of accumulated pluvial precipitation in 24 hours in the state of Puebla, considering 768 different combinations of physical parameters, compared to rain records of weather stations for the period from June 1 to August 20,2017. In addition, as part of the research, optimal configurations are defined to obtain the best performance of the model at local and state levels.
\end{abstract}

Keywords: WRF model, physical parameterizations, pluvial precipitation, state of Puebla.

\section{Introduction}

Mexico is located within the field of influence of tropical cyclones in its different scales (tropical depressions, tropical storms and hurricanes), that are generated both in the Pacific Ocean and in the Atlantic Ocean (Jáuregui, 1989). The intense rains associated with these phenomena can cause flooding and landslides not only on the coasts but also in 
the interior of the territory, causing loss of human life and considerable economic damage, which can sometimes have catastrophic tints (Aparicio, 1998; Douben, 2006). The increase in floods has occurred particularly in urban areas, negatively affecting the normal functioning of the social, service, economic and financial sectors, among others, leaving the population with fewer resources and in greater vulnerability (Benjamín, 2008). In addition, Mexico is also frequently affected by other meteorological phenomena, such as cold fronts and mesoscale convective systems (Hernández-Uribe et al., 2017), independently of cyclonic activity.

The state of Puebla has historically presented the problem of flooding. The summary of damages caused by rains, floods, and tropical cyclones for the year 2008 amounted to 2070 people affected, 414 damaged homes and four deteriorated schools, adding economic damages for a total of 2.5 million pesos (SEGOB, 2009).

The Comisión Nacional del Agua (National Water Commission, CONAGUA) informed that rainfall recorded in the northern and northeastern mountains of the state of Puebla for August 10, 2017 as a result of Hurricane Franklin's passage, broke various historical records. In the Zacapoaxtla weather station, $281 \mathrm{~mm}$ of rainfall were recorded, which exceeded the historical maximum of $204 \mathrm{~mm}$ recorded on August 9, 2012. Meanwhile, a precipitation of 225 $\mathrm{mm}$ was recorded at La Soledad station, a value that exceeds the historical maximum of $212 \mathrm{~mm}$ recorded on August 8, 1979. Lastly, the Zaragoza station reported $198 \mathrm{~mm}$ of precipitation, higher than the historical maximum of $141.1 \mathrm{~mm}$ of August 5, 1975 (CONAGUA, 2017). The Atlas of water vulnerability to climate change in Mexico (Arreguín-Cortés et al., 2015), points out that the municipalities of Cuetzalan del Progreso and Zacapoaxtla, located in the northwest of the state, present a high risk given the current rainfall and tropical cyclone conditions.

In the face of this problem, Numerical Weather Prediction (NWP) constitutes a basic tool to understand, explain and predict the behavior of the atmosphere. The Weather Research and Forecasting (WRF) model has a great acceptance and is used worldwide, both by the scientific community, academics, predictors and decision makers. However, like other dynamic and statistical models, WRF is not perfect, so it is necessary to evaluate its performance in each region. For the particular case of the state of Puebla, the performance of the WRF model for high spatial resolution forecasts of precipitation (which allows the quantitative determination of the degree of confidence and defines the set of optimal physical conditions) has not been evaluated.

The two main objectives of this research were to quantitatively evaluate the performance of the WRF model to simulate precipitation in the state of Puebla, considering different combinations of physical parameters, and compare the results with the rain records obtained from the weather stations during the summer of 2017; and to determine the optimal configurations of the WRF model for obtaining its best performance in the state of Puebla.

\section{Dataset and methods}

In the particular sense of the experimental approach, one or more independent variables are intentionally manipulated (alleged causes background) to analyze the consequences of this procedure on one or more dependent variables (supposed consequential effects) within a control situation for the researcher (Campbell and Stanley, 2012; Creswell, 2013; White and McBurney, 2013; Babbie, 2014; Hernández-Sampieri et al., 2014).

This study is quantitative and experimental. It considers independent variables (the physical parameterizations of the WRF model) and a dependent variable (the rainfall precipitation generated by the WRF model). The manipulation or variation of independent variables was done in eight degrees. Each one of these levels comprises a group in the experiment, corresponding to the variation of the parameters of microphysics (mp_physics), convection (physics), planetary limit layer (bl_pbl_physics), surface layer (sf_sfclay_physics), soil surface (sf_surface_physics), short wave radiation (ra lw_phphics), long wave radiation (ra_sw_physics) and the time interval between calls to the convection parameterization (cudt).

There is no rule to determine the number of independent and dependent variables that should be included in an experiment. This depends on the approach to the research problem and the existing limitations (Henríquez-Fierro and Zepeda-González, 2003). 
The spectrum of combinations of possible physical parameters in the WRF model is very wide, more than 16 million in the ARW core. For this study, a total of 768 experimental groups were defined, each corresponding to the different levels of variation of the selected physical parameters.

To measure the effect of different experiments, statistical metrics were applied between the simulated precipitation and the accumulated rainfall records in $24 \mathrm{~h}$ in weather stations installed in the state of Puebla, where summers are rainier than other seasons of the year. For this reason, summer (from June 1 to August 20, 2017) was chosen as the study period. Further, during this time, the state of Puebla received the onslaught of Hurricane Franklin, which caused torrential rains that exceeded the historical highs in the state.

\subsection{Study zone}

The state of Puebla is located in the central part of Mexico. It borders to the north with the states of Hidalgo and Veracruz; to the east also with Veracruz and Oaxaca; to the south with the latter and Guerrero, and to the west with this state, Morelos, Mexico, Tlaxcala and Hidalgo (Tamayo, 1996). It has an area of $34290 \mathrm{~km}^{2}$, which represents $17 \%$ of the total national space. It is characterized by a wide topographical heterogeneity because it houses four major biogeographical provinces: The Sierra Madre Oriental, the coastal plain of the North Gulf, the Neovolcanic Axis, and the Sierra Madre del Sur. This geomorphological diversity causes marked changes in altitude, which give rise to a wide variety of climates, dominating the temperate climates that cover most of the territory, followed by warm and semi-arid climates. The climatic heterogeneity is due, in part, to the fact that as altitude increases, temperature decreases and $65 \%$ of the territory of Puebla is composed of mountainous topography and hills.

\subsection{Description of the WRF model}

The performance of numerical models of weather prediction has increased in the last 40 years due mainly to four factors (Kalnay, 2003): (1) The increase in computing power of supercomputers, allowing a finer numerical resolution and fewer approximations in operational atmospheric models; (2) the improvement of the representation of small-scale physical processes within the models (clouds, precipitation, turbulent heat transfer, humidity, momentum and radiation); (3) the use of more accurate data assimilation methods, which results in an improvement of the initial conditions for the model, and (4) the increase in data availability, especially satellite and aircraft data on the oceans and the southern hemisphere.

The main features of the WRF model revolve around its non-hydrostatic dynamics and its ability to process spatial resolutions of a few kilometers (Moya-Álvarez and Ortega-León, 2015). About its structure, the WRF model has two dynamic cores (Advanced Research WRF [ARW] and Nonhydrostatic Mesoscale Mode [NMM]), a data assimilation system, and a software architecture that allows the application of parallel computing to perform simulations (Skamarock et al., 2008). In this study, the dynamic core WRF-ARW version 3.9.1.1 was used. The WRF modeling system requires external data sources and consists of three main modules: (1) the WRF preprocessing system (WPS); (2) the ARW solver, and (3) third-party postprocessing and visualization tools.

\subsection{Dataset}

The forecast accuracy of the models lies primarily in a good description of the initial state of the atmosphere. This initial state, analysis or first approximation is created by an optimal combination between observed data and a short-term forecast derived from a previous analysis through a process known as data assimilation. According to Zepka (2011), for satisfactory results regarding the predictability of a storm or any adverse weather phenomenon characterized by very small spatial and time dimensions, high-quality input data with high temporal and spatial resolutions are necessary, as well as a high-resolution model.

The WRF model requires knowledge of the initial and boundary conditions for the simulation period at constant time intervals, information which is usually incorporated from global data. For this study, we chose to use the data from the Global Forecast System (GFS) model, which is a reference for operational forecasting and research studies. GFS data was downloaded from ftp://ftp.ncep.noaa.gov/pub/ data/nccf/com/gfs/prod.

Daily rainfall records were obtained from the Hydrological Information System (HIS) developed in the 
Surface Water and River Engineering Management of CONAGUA, through the site http://148.204.8.145. The HIS is a system sponsored by the World Meteorological Organization (WMO) through the Water Management Modernization Program.

Fifty-four weather stations with at least $80 \%$ data in the study period were selected as sampling units. Table I lists the 54 selected weather stations with their corresponding keys, and Figure 1 their geographical location within the state of Puebla.

\subsection{Experiment design}

Two domains were defined for the execution of the WRF model, the mother domain with a spatial resolution of $16 \mathrm{~km}$ and a nested domain with a resolution of $8 \mathrm{~km}$. Only simulated precipitation in the nested domain was used to evaluate the performance of the WRF model in the state of Puebla. Table II shows the fixed parameters selected for experimentation with the WRF model.

As mentioned above, 768 experiments with the WRF model were executed, each one corresponding to one of the possible combinations of the different physical settings selected. Each parameterization was varied in two options, except for the convection parameterization, from which six different ones were selected since precipitation is directly associated with the formation of clouds. However, all the different physical parameterizations affect the simulation of precipitation. The combination was selected on a discretionary basis of the compatibility at the run time between different combinations. Table III lists the physical parameters considered in the 768 experiments.

The results of the experiments were sorted by date and weather station, generating a text file consisting of 81 lines which corresponds to the analysis days of the period from June 1 to August 20, 2017. Each line contains 770 columns, the first one containing the date; the second column contains the observed precipitation value, and columns 3 through 770 contain the precipitation value simulated by the WRF model in each of the 768 experiments.

\subsection{Metrics to measure the performance of the WRF model}

In systems modeling, an essential stage that presents both conceptual and practical difficulties is the validation of the models. An important part of this process is empirical validation, which according to Reynolds (1984) and Mitchell (1997) is done to compare the predictions of the model with observations from the real world. According to Aguilar (1997) and Rauscher et al. (2000), these comparisons should ideally be carried out using appropriate statistical methods, with an acceptable level of confidence, so that the inferences are correct (Barrales et al., 2004).

There are different methods to quantitatively validate numerical forecast models, highlighting the use of simple statistics of bias, root mean square error (RMSE) and Pearson correlation. These parameters were selected because they are not exclusive and can be used together. Among the works that propose and use these statistical parameters for the evaluation of forecast models are Willmott (1982), Pielke (1984), Willmott et al. (1985), Carbonell et al. (2003) and Das et al. (2015).

The selected statistics were applied to each observation site for both the set of observed data $(\mathrm{O})$ and model predictions $(\mathrm{P})$. To the extent that the statistical indicators are favorable and show that the simulated data are approximate to observed data, and that the behavior over time of simulated variables is similar to that observed, it can be concluded that the simulation provides representative data and that the WRF model can simulate the precipitation in the state of Puebla (Gavidia, 2012).

RMSE is a measure of quantitative performance commonly used to evaluate forecasting methods. In this context, RMSE consists in the square root of the sum of the quadratic errors, which captures positive errors as negative; therefore, it expresses both systematic and random errors. RMSE amplifies and penalizes with greater force those errors of greater magnitude (Eq. 1).

$R M S E=\sqrt{\frac{1}{n} \sum_{i=1}^{n}\left(P_{i}-O_{i}\right)^{2}}$

where $P_{i}$ is the prediction of the model in position $i, O_{i}$ is the value observed in position $i$ and $n$ is the sample size.

The bias is a consistent, constant, and one-way error. It can be positive (overestimation) or negative (underestimation), which does not depend on the number of elements but on many other factors that can be controlled in general if their existence is suspected and the research is carefully planned and executed (Moya de Madrigal, 2005). This statistic measures the reliability of the model, revealing the 
Table I. List of the 54 weather stations selected in the state of Puebla.

\begin{tabular}{|c|c|c|c|c|c|}
\hline No. & Key & Name & Latitude & Longitude & $\begin{array}{c}\text { Altitude } \\
\text { (masl) }\end{array}$ \\
\hline 1 & ACHPB & Alchichilca & 19.450000 & -97.418056 & 2340 \\
\hline 2 & ACJPB & Acajete & 19.062500 & -97.934167 & 2330 \\
\hline 3 & ADOPB & Acatlán de Osorio & 18.277222 & -98.055000 & 1270 \\
\hline 4 & AFRPB & Africam & 18.942500 & -98.135833 & 2120 \\
\hline 5 & AHAPB & Ahuatepec & 18.854167 & -97.920833 & 2000 \\
\hline 6 & AHUPB & Ahuazontepec & 20.033056 & -98.148056 & 2216 \\
\hline 7 & APAPB & Apapantilla & 20.406944 & -97.845000 & 2970 \\
\hline 8 & ATXPB & Atlixco & 18.921111 & -98.420833 & 1855 \\
\hline 9 & AVCPB & Ávila Camacho & 20.385833 & -97.881111 & 240 \\
\hline 10 & CDSPB & Cd. Serdán & 18.987222 & -97.441667 & 2550 \\
\hline 11 & CEMPB & Cemex & 18.968889 & -97.958333 & 2225 \\
\hline 12 & CHIPB & Chietla & 18.516111 & -98.579167 & 929 \\
\hline 13 & CHLPB & Cholula & 19.068611 & -98.318056 & 2155 \\
\hline 14 & CHSPB & Chila de la Sal & 18.109722 & -98.567778 & 940 \\
\hline 15 & CNAPB & C.N.A. & 19.022778 & -98.198611 & 2150 \\
\hline 16 & CNGPB & Chignahuapan & 19.743333 & -98.049722 & 2300 \\
\hline 17 & COAPB & Coatzingo & 18.612778 & -98.164722 & 1210 \\
\hline 18 & CPLPB & Capulac & 19.092778 & -98.059444 & 2430 \\
\hline 19 & CTZPB & Cuetzalan & 20.033333 & -97.516667 & 980 \\
\hline 20 & ЕCHPB & Echeverría & 18.966111 & -98.275556 & 2075 \\
\hline 21 & ELCPB & El Carmen & 20.083333 & -98.116667 & 2160 \\
\hline 22 & НJTPB & Huejotzingo & 19.101111 & -98.456111 & 2260 \\
\hline 23 & HQCPB & Huaquechula & 18.772222 & -98.540278 & 1580 \\
\hline 24 & HUAPB & Huauchinango & 20.176389 & -98.050833 & 1472 \\
\hline 25 & IZMPB & Izúcar de Matamoros & 18.610833 & -98.466389 & 1260 \\
\hline 26 & LIBPB & Libres & 19.457222 & -97.691111 & 2430 \\
\hline 27 & MAYPB & Mayorazgo 21 Pte. & 19.010556 & -98.231111 & 2122 \\
\hline 28 & NNEPB & Nuevo Necaxa & 20.216667 & -98.000556 & 1364 \\
\hline 29 & OYAPB & Oyameles & 19.700000 & -97.533333 & 2850 \\
\hline 30 & PCRPB & Paso Carretas & 18.918056 & -97.251389 & 2600 \\
\hline 31 & PIXPB & Piaxtla & 18.200000 & -98.264722 & 1119 \\
\hline 32 & PTLPB & Patla & 20.233333 & -97.883333 & 525 \\
\hline 33 & PUOPB & Puebla Observatorio & 19.050000 & -98.166667 & 2179 \\
\hline 34 & QUIPB & Quimixtlán & 19.250000 & -97.616667 & 2070 \\
\hline 35 & RNAPB & Rancho Nuevo (Ayotoxco) & 20.116111 & -97.401667 & 366 \\
\hline 36 & SCRPB & San Cristóbal Caleras & 19.113056 & -98.220000 & 2513 \\
\hline 37 & SMCPB & San Miguel Canoa & 18.735000 & -97.910000 & 2583 \\
\hline 38 & SOLPB & La Soledad & 19.960833 & -97.446667 & 1590 \\
\hline 39 & TDRPB & Tepango de Rodríguez & 20.004444 & -97.792500 & 1560 \\
\hline 40 & ТЕСРВ & Tecamachalco & 18.878889 & -97.752500 & 2030 \\
\hline 41 & TEHPB & Tehuacán & 18.479167 & -97.395556 & 1648 \\
\hline 42 & TEOPB & Tetela de Ocampo & 19.829444 & -97.805833 & 1725 \\
\hline 43 & ТЕРPВ & Tepexic & 20.000833 & -97.794167 & 1526 \\
\hline 44 & TEZPB & Teziutlán & 19.815278 & -97.956944 & 1950 \\
\hline 45 & TLPPB & Tlacotepec de Díaz & 18.405000 & -96.849722 & 300 \\
\hline 46 & TLXPB & Tlaxco & 20.374167 & -98.040556 & 1065 \\
\hline 47 & ТРYРВ & Tepeyahualco & 19.489167 & -97.491944 & 2924 \\
\hline 48 & TYAPB & Tepeyac & 18.483611 & -96.861389 & 100 \\
\hline 49 & UDSPB & Universidad de la Sierra & 20.176389 & -98.050833 & 1472 \\
\hline 50 & VENPB & Venustiano Carranza & 20.510278 & -97.675833 & 1200 \\
\hline
\end{tabular}


Table I. List of the 54 weather stations selected in the state of Puebla.

\begin{tabular}{lllccc}
\hline No. & Key & Name & Latitude & Longitude & $\begin{array}{c}\text { Altitude } \\
\text { (masl) }\end{array}$ \\
\hline 51 & XDJPB & Xicotepec de Juárez & 20.277222 & -97.956944 & 1180 \\
52 & ZCPPB & Zacapoaxtla & 19.859722 & -97.585000 & 2045 \\
53 & ZOQPB & Zoquitlán & 18.332222 & -97.011389 & 2175 \\
54 & ZRGPB & Zaragoza & 20.178611 & -97.832778 & 2493 \\
\hline
\end{tabular}
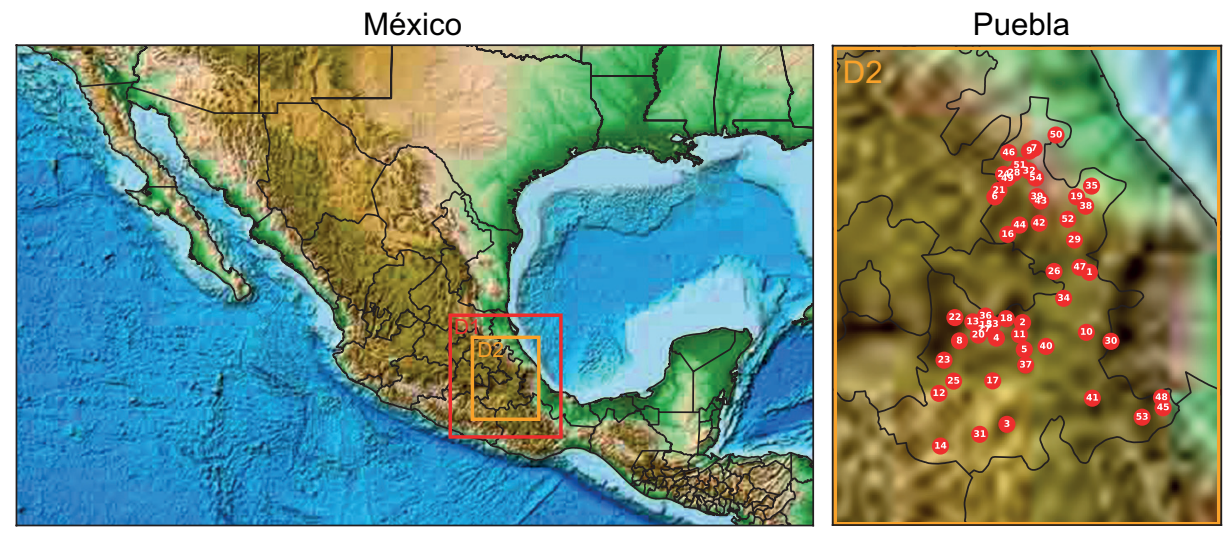

Fig. 1. Geographical location of the selected weather stations in the state of Puebla (right). The station number corresponds to the list of stations in Table I. Experimentation domains with the WRF model (D1 [mother domain, red] and D2 [nested domain, orange]) are marked on the map of Mexico (left).

Table II. Fixed parameters selected for experimentation with the WRF model.

\begin{tabular}{llcc}
\hline Parameter & Description & Mother domain & Nested domain \\
\hline $\mathrm{dx}$ & Grid length in x direction $(\mathrm{m})$ & 16000 & 8000 \\
$\mathrm{dy}$ & Grid length in y direction (m) & 16000 & 8000 \\
map_proj & Map projection & Mercator & Mercator \\
time_step & Time step for integration in integer seconds & 96 & 96 \\
history_interval & History output file interval (min) & 180 & 60 \\
ref_lat & Central latitude of the mother domain & 19.3453 & 19.3453 \\
ref_lon & Central length of mother domain & -97.9065 & -97.9065 \\
e_we & End index in x direction (west-east) & 47 & 59 \\
e_sn & End index in y direction (south-north) & 51 & 67 \\
i_parent_start & Starting lower left corner I-indices from the mother domain & 1 & 8 \\
j_parent_start & Starting lower left corner J-indices from the mother domain & 1 & 8 \\
\hline
\end{tabular}

systematic error. Not having a bias or having a minimal one is a desirable property which indicates that the forecast is close to reality (Eq. 2).

$$
B I A S=\frac{1}{n} \sum_{i=1}^{n}\left(P_{i}-O_{i}\right)^{2}=\bar{P}-\bar{O}
$$


Table III. Physical parameters considered in the 768 experiments.

\begin{tabular}{|c|c|}
\hline $\begin{array}{l}\text { Option } \\
\text { number }\end{array}$ & Parameterization \\
\hline \multicolumn{2}{|r|}{ Microphysics } \\
\hline 2 & Lin et al. scheme \\
\hline 4 & WRF Single-Moment (WSM) 5-class scheme \\
\hline \multicolumn{2}{|r|}{ Convection } \\
\hline 1 & Kain-Fritsch (new Eta) scheme \\
\hline 2 & Betts-Miller-Janjic scheme \\
\hline 3 & Grell-Devenyi ensemble scheme \\
\hline 5 & Grell 3D ensemble scheme \\
\hline 6 & Modifed Tiedtke scheme \\
\hline 14 & $\begin{array}{l}\text { New GFS simplified Arakawa-Schubert } \\
\text { scheme from YSU }\end{array}$ \\
\hline \multicolumn{2}{|r|}{ Planetary boundary layer } \\
\hline 1 & YSU scheme \\
\hline 2 & Mellor-Yamada-Janjic (Eta) TKE scheme \\
\hline \multicolumn{2}{|r|}{ Surface layer } \\
\hline 1 & Monin-Obukhov similarity scheme \\
\hline 2 & Monin-Obukhov (Janjic Eta) similarity scheme \\
\hline \multicolumn{2}{|r|}{ Soil surface } \\
\hline 1 & Thermal diffusion scheme \\
\hline 2 & Noah land-surface model \\
\hline \multicolumn{2}{|r|}{ Short wave radiation } \\
\hline 1 & RRTM scheme \\
\hline 3 & CAM scheme \\
\hline \multicolumn{2}{|r|}{ Long wave radiation } \\
\hline 1 & Dudhia scheme \\
\hline 2 & Goddard shortwave scheme \\
\hline \multicolumn{2}{|r|}{ Time step for the convection } \\
\hline 10 & 10 minutes \\
\hline 30 & 30 minutes \\
\hline
\end{tabular}

where $P_{i}$ is the prediction of the model in position $i, O_{i}$ is the value observed in position $i$, and $n$ is the sample size.

Pearson correlation, denoted by the letter $r$, is a normalized measure of the linear relationship between two continuous quantitative variables, that is, it measures the dependence of one variable with respect to another independent variable. The Pearson correlation coefficient allows establishing similarities or dissimilarities between variables, to make evident the joint variability and therefore typify what happens with the data (Mondragón-Barrera, 2014 ). The coefficient can score values ranging from -1.0 to 1.0 . Values close to 1.0 indicate that there is a strong association between the variables, that is, when one increases the other as well. On the other hand, values close to -1.0 indicate that there is a strong negative association between the variables, implying that when one variable increases, the other decreases. When the value is 0.0 , it indicates that there is no correlation, or the correlation is null (Anderson et al., 2008). In the correlation, the dependent variable is not distinguished from the independent one, so the correlation of $\mathrm{O}$ with respect to $\mathrm{P}$ is the same as the correlation of $\mathrm{P}$ with respect to $\mathrm{O}$ (Eq. 3).

$$
r=\frac{\sum\left(O_{i}-\bar{O}\right)\left(P_{i}-\bar{P}\right)}{\sqrt{\left[\sum\left(O_{i}-\bar{O}\right)^{2}\right]} \sqrt{\left[\sum\left(P_{i}-\bar{P}\right)^{2}\right]}}
$$

where $O_{i}$ is the value observed in position $i, P_{i}$ is the prediction of the model in position $i, \bar{P}$ is the mean observed value, and $\bar{P}$ is the mean model prediction.

The efficiency multiparameter index (EMI) was used to identify exposed cases with better performance at the state level, which involves four steps:

1. Calculation of the statistical metrics of bias, RMSE and $r$ in the 768 experimental groups of the 54 observation sites.

2. Assignment of weights to each experiment according to the level of efficiency in each of the three statistical metrics by location.

3. Application of the EMI (Eq. 4). EMI values range from 0 to 1 , and are interpreted as deficient $(0.0$ $<0.2)$, regular $(0.2<0.4)$, good $(0.4<0.6)$, very good $(0.6<8.0)$ and excellent $(0.8 \leq 1.0)$.

4. Selection of the experiment with the highest EMI as a reference at the state level.

$$
E M I_{e}=\frac{\sum E_{\text {elm }}}{n e * n l * n m}
$$

where $E M I_{\mathrm{e}}$ is the efficiency multiparameter index for experiment $e, n e$ the number of experiments, $n l$ the number of locations, $\mathrm{nm}$ the number of metrics, and $E_{\mathrm{eml}}$ the weight of the experiment $e$ for the metric $m$ and the location $l$. 


\section{Results}

3.1. Precipitation variability during the study

Given that the year 2017 presented a neutral ENSO condition, rainfall in the state of Puebla during the study period was normal with the exception of August 10, 2017 when in the northern and eastern regions of the state, precipitation from very strong to intense occurred with values exceeding $75 \mathrm{~mm}$ accumulated in $24 \mathrm{~h}$. This extraordinary precipitation was caused by hurricane Franklin (category 1), which hit land on August 10 at 00:00 LT in the state of Veracruz and subsequently weakened at 4:00 LT to a tropical storm in the northern highlands of Puebla.

\subsection{Analysis and interpretation of results}

A first analysis was performed with the results of the statistical evaluation parameters in the 54 locations. Table IV shows the minimum and maximum values in the 768 experiments by weather station and statistical metrics.

Overall, the 768 experiments tend to underestimate precipitation with negative biases in 33 observation sites, positive biases with a tendency to overestimate precipitation in only six sites, and a mixed trend in 15 locations. Extreme biases in the 54 locations were presented in the interval $[-41.96$, 18.06].

On the other hand, the different experiments with the WRF model gave RMSEs in the interval [3.14, 69.73]. The lowest RMSE was obtained at ACHPB, AHUPB, CNGPB, CDSPB, TEHPB and TPYPB stations with intervals [3.18, 13.52], [4.71, 20.51], $[5.0,26.36],[4.65,19.66],[4.02,18.83]$, and [3.14, 15.92], respectively. At the opposite end, the WRF model presented the highest RMSE at the HJTPB and TLPPB stations with intervals [15.53, 55.27] and [8.25, 69.73], respectively.

Regarding the Pearson correlation parameter, the results are very varied in the same location. In the 768 experiments both negative and positive correlations were observed, the latter predominating. Under this metric, the WRF model achieved extremely high positive correlations with values greater than 0.9 at the AHUPB, CDSPB, OYAPB, TECPB, TEOPB, TPYPB, ZCPPB, and ZRGPB observation sites. Meanwhile, through the different 768 configurations, the lowest correlations were obtained at stations CTZPB, TEZPB and ZOQPB stations with intervals of $[-0.04,0.27],[-0.08,0.06]$ and $[-0.04$, 0.27 , respectively.

A second analysis of results was performed by grouping the observation sites into six groups with ranges of 500 masl, as shown in Table V. It was observed that at altitudes above 2000 masl, corresponding to groups five and six (which together concentrate $50 \%$ of the weather stations), the WRF model has better performance, especially in the central and northern region of the state of Puebla, with the exception of the ZOQPB station, where moderate performance was observed. The region in which the WRF model generally presented the lowest performance was the southwest of the state. The contrast between the 768 experimental groups in the same observation site is evident, starting with performances from low to very high. These results emphasize the importance of conducting experiments to determine the appropriate configuration according to the study area. The exception is the CNGPB station, located to the north of the state of Puebla at an altitude of 2300 masl, where the WRF model in all experiments presented medium to very high performance, with bias in the interval [-11.85, 1.61], an RMSE maximum of 26.36 and $r$ greater than 0.29 ; however, a bad configuration of the WRF model physical parameters in this station would not present, in statistical terms, serious errors in the simulation of precipitation.

\subsection{Optimal configuration of the WRF model}

Three optimal configurations were determined to execute the WRF model by location, each one corresponding to the experiment which obtained the better performance in the three evaluation metrics. Tables VI, VII and VIII describe the optimal configurations according to the statistical parameters of bias, RMSE, and Pearson correlation, respectively.

The results show that no single experiment has the best performance for the WRF model in all the observation sites, nor in the three statistical metrics. Although some experiments with high performance in different metrics and observation sites were identified, they were scarce.

The experiment with control number 571 obtained the best performance at the state level according to the EMI, with a very good value of 0.76 . Table IX shows the 10 experiments with highest EMI values. After analyzing the 10 best configurations according 
Table IV. Minimum and maximum values in the 768 experiments by statistical metric and weather station.

\begin{tabular}{|c|c|c|c|c|c|c|}
\hline \multirow{2}{*}{ Station key } & \multicolumn{2}{|c|}{ BIAS } & \multicolumn{2}{|c|}{ RMSE } & \multicolumn{2}{|c|}{$\mathrm{r}$} \\
\hline & Minimun & Maximum & Minimun & Maximum & Minimun & Maximum \\
\hline ACHPB & 0.01 & 1.16 & 3.18 & 13.52 & 0.07 & 0.85 \\
\hline ACJPB & 0.01 & 1.89 & 5.70 & 34.74 & 0.21 & 0.67 \\
\hline ADOPB & 6.89 & 5.15 & 7.95 & 22.09 & 0.12 & 0.68 \\
\hline AFRPB & 3.77 & 5.26 & 9.85 & 29.51 & 0.06 & 0.52 \\
\hline АНАРВ & -0.01 & 3.53 & 6.94 & 28.74 & 0.16 & 0.79 \\
\hline AHUPB & 0.02 & 3.12 & 4.71 & 20.51 & 0.17 & 0.92 \\
\hline APAPB & -0.03 & 9.36 & 15.13 & 30.14 & 0.03 & 0.72 \\
\hline АТХPB & 0.01 & 4.60 & 7.81 & 24.53 & 0.06 & 0.57 \\
\hline AVCPB & 0.01 & 7.04 & 14.46 & 34.25 & 0.01 & 0.50 \\
\hline CDSPB & -0.01 & 1.94 & 4.65 & 19.66 & 0.05 & 0.91 \\
\hline CEMPB & -0.01 & 3.38 & 7.63 & 31.26 & 0.08 & 0.68 \\
\hline CHIPB & -0.01 & 4.57 & 7.82 & 44.97 & -0.02 & 0.49 \\
\hline CHLPB & -0.01 & 7.06 & 9.11 & 27.29 & 0.12 & 0.61 \\
\hline CHSPB & -0.01 & 5.19 & 10.59 & 24.47 & -0.07 & 0.44 \\
\hline CNAPB & 0.01 & 6.17 & 9.46 & 32.02 & 0.04 & 0.51 \\
\hline CNGPB & -0.02 & 1.61 & 5.00 & 26.36 & 0.29 & 0.88 \\
\hline COAPB & 0.01 & 5.64 & 10.86 & 29.90 & 0.00 & 0.87 \\
\hline CPLPB & -0.15 & 2.92 & 6.28 & 31.48 & 0.15 & 0.62 \\
\hline СТZРВ & -0.02 & 10.73 & 21.31 & 43.26 & -0.04 & 0.27 \\
\hline ЕСНРB & -0.01 & 5.73 & 10.91 & 32.81 & 0.09 & 0.63 \\
\hline ELCPB & -0.01 & 3.49 & 5.63 & 32.99 & -0.01 & 0.88 \\
\hline НJTPB & 0.01 & 4.72 & 7.18 & 20.78 & 0.08 & 0.62 \\
\hline HQCPB & 0.03 & 5.50 & 8.28 & 41.70 & 0.09 & 0.68 \\
\hline HUAPB & 0.02 & 6.42 & 9.68 & 32.22 & 0.05 & 0.82 \\
\hline IZMPB & -0.01 & 4.91 & 7.87 & 39.48 & -0.06 & 0.49 \\
\hline LIBPB & 0.01 & 1.70 & 6.15 & 24.74 & 0.04 & 0.78 \\
\hline MAYPB & -0.01 & 4.37 & 9.55 & 33.45 & -0.03 & 0.52 \\
\hline NNEPB & -0.01 & 6.82 & 10.88 & 42.27 & -0.06 & 0.71 \\
\hline OYAPB & 0.03 & 0.50 & 6.69 & 37.95 & -0.06 & 0.98 \\
\hline PCRPB & 0.02 & 3.10 & 7.77 & 35.20 & -0.05 & 0.71 \\
\hline PIXPB & 0.01 & 2.79 & 6.96 & 30.98 & -0.04 & 0.60 \\
\hline PTLPB & -0.01 & 10.22 & 12.84 & 31.63 & 0.07 & 0.68 \\
\hline PUOPB & 0.01 & 5.94 & 10.49 & 33.13 & 0.10 & 0.57 \\
\hline QUIPB & -0.01 & 7.04 & 12.85 & 24.81 & 0.03 & 0.52 \\
\hline RNAPB & 0.01 & 6.92 & 14.66 & 24.42 & 0.04 & 0.74 \\
\hline SCRPB & -0.01 & 7.26 & 11.46 & 31.71 & -0.02 & 0.56 \\
\hline SMCPB & -0.01 & 2.57 & 6.60 & 27.81 & -0.07 & 0.50 \\
\hline SOLPB & -0.01 & 11.99 & 15.53 & 55.27 & -0.07 & 0.86 \\
\hline TDRPB & -0.01 & 12.06 & 16.93 & 39.78 & -0.04 & 0.86 \\
\hline ТЕСРВ & -0.01 & 1.09 & 5.58 & 28.05 & -0.06 & 0.93 \\
\hline TEHPB & 0.01 & 0.18 & 4.02 & 18.83 & -0.07 & 0.49 \\
\hline TEOPB & -0.01 & 5.16 & 7.91 & 25.87 & -0.02 & 0.95 \\
\hline ТЕРPB & 0.01 & 7.63 & 11.64 & 31.04 & 0.02 & 0.73 \\
\hline TEZPB & -0.01 & 5.98 & 25.54 & 33.67 & -0.08 & 0.06 \\
\hline TLPPB & 0.01 & 18.06 & 28.00 & 34.46 & -0.05 & 0.33 \\
\hline TLXPB & 0.02 & 3.20 & 6.92 & 33.49 & 0.03 & 0.51 \\
\hline ТРYРВ & 0.01 & 1.15 & 3.14 & 15.92 & 0.23 & 0.92 \\
\hline TYAPB & -0.01 & 14.77 & 21.83 & 29.91 & -0.10 & 0.36 \\
\hline UDSPB & 0.01 & 7.23 & 10.58 & 41.61 & 0.05 & 0.77 \\
\hline VENPB & -0.02 & 2.58 & 8.85 & 22.24 & 0.04 & 0.67 \\
\hline
\end{tabular}


Table IV. Minimum and maximum values in the 768 experiments by statistical metric and weather station.

\begin{tabular}{lcccccc}
\hline \multirow{2}{*}{ Station key } & \multicolumn{2}{c}{ BIAS } & \multicolumn{2}{c}{ RMSE } & \multicolumn{2}{c}{ r } \\
\cline { 2 - 6 } & Minimun & Maximum & Minimun & Maximum & Minimun & Maximum \\
\hline XDJPB & 0.01 & 11.48 & 14.69 & 40.96 & 0.06 & 0.78 \\
ZCPPB & -0.01 & 3.73 & 8.25 & 69.73 & -0.06 & 0.98 \\
ZOQPB & -0.01 & 6.47 & 13.73 & 30.46 & -0.04 & 0.27 \\
ZRGPB & 0.01 & 3.54 & 8.75 & 41.73 & -0.07 & 0.98 \\
Mean & 0.19 & 5.49 & 10.13 & 31.85 & 0.03 & 0.67 \\
\hline
\end{tabular}

Table V. Experiments with better performance by statistical metrics and weather station.

\begin{tabular}{|c|c|c|c|c|c|c|c|c|}
\hline \multirow{2}{*}{$\begin{array}{l}\text { Group } \\
\text { number }\end{array}$} & \multirow{2}{*}{$\begin{array}{c}\text { Station } \\
\text { key }\end{array}$} & \multirow[b]{2}{*}{ Altitude } & \multicolumn{2}{|c|}{ BIAS } & \multicolumn{2}{|c|}{ RMSE } & \multicolumn{2}{|l|}{$r$} \\
\hline & & & $\begin{array}{l}\text { Experiment } \\
\text { number }\end{array}$ & Value & $\begin{array}{l}\text { Experiment } \\
\text { number }\end{array}$ & Value & $\begin{array}{l}\text { Experiment } \\
\text { number }\end{array}$ & Value \\
\hline \multirow{4}{*}{1} & AVCPB & 240 & 223 & 0.01 & 141 & 14.46 & 141 & 0.50 \\
\hline & RNAPB & 360 & 378 & 0.01 & 589 & 14.66 & 269 & 0.74 \\
\hline & TLPPB & 300 & 59 & 6.89 & 538 & 28.00 & 538 & 0.33 \\
\hline & TYAPB & 100 & 60 & 3.77 & 597 & 21.83 & 259 & 0.36 \\
\hline \multirow{4}{*}{2} & CHIPB & 929 & 656 & -0.01 & 314 & 7.82 & 273 & 0.49 \\
\hline & CHSPB & 940 & 713 & 0.02 & 390 & 10.59 & 1 & 0.44 \\
\hline & СТZРB & 980 & 55 & -0.03 & 747 & 21.31 & 747 & 0.27 \\
\hline & PTLPB & 525 & 410 & 0.01 & 341 & 12.84 & 341 & 0.68 \\
\hline \multirow{10}{*}{3} & ADOPB & 1270 & 189 & 0.01 & 343 & 7.95 & 343 & 0.68 \\
\hline & COAPB & 1210 & 442 & -0.01 & 279 & 10.86 & 279 & 0.87 \\
\hline & HUAPB & 1472 & 242 & -0.01 & 318 & 9.68 & 277 & 0.82 \\
\hline & IZMPB & 1260 & 207 & -0.01 & 718 & 7.87 & 192 & 0.49 \\
\hline & NNEPB & 1364 & 45 & -0.01 & 334 & 10.88 & 140 & 0.71 \\
\hline & PIXPB & 1119 & 133 & -0.01 & 626 & 6.96 & 565 & 0.60 \\
\hline & TLXPB & 1065 & 467 & 0.01 & 725 & 6.92 & 725 & 0.51 \\
\hline & UDSPB & 1472 & 123 & -0.02 & 618 & 10.58 & 9 & 0.77 \\
\hline & VENPB & 1200 & 137 & 0.01 & 621 & 8.85 & 646 & 0.67 \\
\hline & XDJPB & 1180 & 394 & -0.15 & 670 & 14.69 & 670 & 0.78 \\
\hline \multirow{9}{*}{4} & AHAPB & 2000 & 533 & -0.02 & 247 & 6.94 & 372 & 0.79 \\
\hline & ATXPB & 1855 & 696 & -0.01 & 222 & 7.81 & 132 & 0.57 \\
\hline & HQCPB & 1580 & 381 & -0.01 & 335 & 8.28 & 6 & 0.68 \\
\hline & SOLPB & 1590 & 226 & 0.01 & 373 & 15.53 & 124 & 0.86 \\
\hline & TDRPB & 1560 & 57 & 0.03 & 493 & 16.93 & 493 & 0.86 \\
\hline & TEHPB & 1648 & 270 & 0.02 & 393 & 4.02 & 397 & 0.49 \\
\hline & TEOPB & 1725 & 153 & -0.01 & 766 & 7.91 & 766 & 0.95 \\
\hline & TEPPB & 1526 & 544 & 0.01 & 10 & 11.64 & 10 & 0.73 \\
\hline & TEZPB & 1950 & 131 & -0.01 & 597 & 25.54 & 456 & 0.06 \\
\hline
\end{tabular}


Table V. Experiments with better performance by statistical metrics and weather station.

\begin{tabular}{|c|c|c|c|c|c|c|c|c|}
\hline \multirow{2}{*}{$\begin{array}{l}\text { Group } \\
\text { number }\end{array}$} & \multirow{2}{*}{$\begin{array}{c}\text { Station } \\
\text { key }\end{array}$} & \multirow[b]{2}{*}{ Altitude } & \multicolumn{2}{|c|}{ BIAS } & \multicolumn{2}{|c|}{ RMSE } & \multicolumn{2}{|c|}{$\mathrm{r}$} \\
\hline & & & $\begin{array}{l}\text { Experiment } \\
\text { number }\end{array}$ & Value & $\begin{array}{l}\text { Experiment } \\
\text { number }\end{array}$ & Value & $\begin{array}{l}\text { Experiment } \\
\text { number }\end{array}$ & Value \\
\hline \multirow{20}{*}{5} & ACHPB & 2340 & 697 & -0.01 & 397 & 3.18 & 512 & 0.85 \\
\hline & АCJPB & 2330 & 693 & 0.03 & 398 & 5.70 & 717 & 0.67 \\
\hline & AFRPB & 2120 & 2 & 0.02 & 206 & 9.85 & 206 & 0.52 \\
\hline & AHUPB & 2216 & 235 & 0.01 & 622 & 4.71 & 256 & 0.92 \\
\hline & CEMPB & 2225 & 526 & -0.01 & 739 & 7.63 & 264 & 0.68 \\
\hline & CHLPB & 2155 & 80 & 0.01 & 718 & 9.11 & 707 & 0.61 \\
\hline & CNAPB & 2150 & 157 & -0.01 & 325 & 9.46 & 218 & 0.51 \\
\hline & CNGPB & 2300 & 330 & 0.01 & 638 & 5.00 & 37 & 0.88 \\
\hline & CPLPB & 2430 & 681 & -0.01 & 325 & 6.28 & 135 & 0.62 \\
\hline & ЕCHPB & 2075 & 534 & -0.01 & 214 & 10.91 & 263 & 0.63 \\
\hline & ELCPB & 2160 & 324 & -0.01 & 323 & 5.63 & 339 & 0.88 \\
\hline & НJTPB & 2260 & 699 & -0.01 & 53 & 7.18 & 452 & 0.62 \\
\hline & LIBPB & 2430 & 541 & -0.01 & 650 & 6.15 & 278 & 0.78 \\
\hline & MAYPB & 2122 & 70 & 0.01 & 213 & 9.55 & 11 & 0.52 \\
\hline & PUOPB & 2179 & 648 & -0.01 & 610 & 10.49 & 610 & 0.57 \\
\hline & QUIPB & 2070 & 559 & 0.01 & 224 & 12.85 & 204 & 0.52 \\
\hline & ТЕСРВ & 2030 & 641 & -0.01 & 247 & 5.58 & 248 & 0.93 \\
\hline & ZCPPB & 2045 & 317 & 0.01 & 347 & 8.25 & 752 & 0.98 \\
\hline & ZOQPB & 2175 & 16 & 0.02 & 370 & 13.73 & 328 & 0.27 \\
\hline & ZRGPB & 2493 & 365 & 0.01 & 22 & 8.75 & 394 & 0.98 \\
\hline \multirow{7}{*}{6} & APAPB & 2970 & 220 & -0.01 & 356 & 15.13 & 752 & 0.72 \\
\hline & CDSPB & 2550 & 78 & 0.01 & 397 & 4.65 & 636 & 0.91 \\
\hline & OYAPB & 2850 & 269 & -0.02 & 314 & 6.69 & 267 & 0.98 \\
\hline & PCRPB & 2600 & 454 & 0.01 & 586 & 7.77 & 517 & 0.71 \\
\hline & SCRPB & 2513 & 717 & -0.01 & 309 & 11.46 & 21 & 0.56 \\
\hline & SMCPB & 2583 & 210 & -0.01 & 470 & 6.60 & 3 & 0.50 \\
\hline & TPYPB & 2924 & 77 & 0.01 & 127 & 3.14 & 686 & 0.92 \\
\hline Mean & & & & 0.19 & & 10.13 & & 0.67 \\
\hline
\end{tabular}

Table VI. Description of the optimal configuration of the WRF model by location according to the BIAS statistical parameter.

\begin{tabular}{|c|c|c|c|c|c|c|c|c|c|}
\hline \multirow{2}{*}{$\begin{array}{l}\text { Station } \\
\text { key }\end{array}$} & \multirow{2}{*}{$\begin{array}{l}\text { Experiment } \\
\text { number }\end{array}$} & \multicolumn{7}{|c|}{ Physical parameters } & \multirow{2}{*}{$\begin{array}{l}\text { Time step } \\
\text { for the } \\
\text { convection }\end{array}$} \\
\hline & & Microphysics & Convection & $\begin{array}{c}\text { Planetary } \\
\text { boundary } \\
\text { layer }\end{array}$ & $\begin{array}{l}\text { Surface } \\
\text { layer }\end{array}$ & $\begin{array}{l}\text { Land } \\
\text { surface }\end{array}$ & $\begin{array}{l}\text { Short wave } \\
\text { radiation }\end{array}$ & $\begin{array}{l}\text { Long wave } \\
\text { radiation }\end{array}$ & \\
\hline ACHPB & 697 & 4 & 6 & 2 & 2 & 2 & 1 & 1 & 10 \\
\hline ACJPB & 693 & 2 & 3 & 2 & 2 & 2 & 3 & 1 & 10 \\
\hline ADOPB & 189 & 2 & 3 & 2 & 2 & 2 & 3 & 1 & 10 \\
\hline AFRPB & 2 & 2 & 1 & 1 & 1 & 1 & 1 & 1 & 30 \\
\hline AHAPB & 533 & 4 & 3 & 1 & 2 & 1 & 3 & 1 & 10 \\
\hline AHUPB & 235 & 2 & 5 & 2 & 1 & 2 & 1 & 2 & 10 \\
\hline APAPB & 220 & 2 & 5 & 1 & 2 & 2 & 1 & 2 & 30 \\
\hline АТХРВ & 696 & 4 & 6 & 2 & 2 & 1 & 3 & 2 & 30 \\
\hline AVCPB & 223 & 2 & 5 & 1 & 2 & 2 & 3 & 2 & 10 \\
\hline CDSPB & 78 & 2 & 2 & 1 & 1 & 2 & 3 & 1 & 30 \\
\hline
\end{tabular}


Table VI. Description of the optimal configuration of the WRF model by location according to the BIAS statistical parameter.

\begin{tabular}{|c|c|c|c|c|c|c|c|c|c|}
\hline \multirow{2}{*}{$\begin{array}{l}\text { Station } \\
\text { key }\end{array}$} & \multirow{2}{*}{$\begin{array}{l}\text { Experiment } \\
\text { number }\end{array}$} & \multicolumn{7}{|c|}{ Physical parameters } & \multirow{2}{*}{$\begin{array}{c}\text { Time step } \\
\text { for the } \\
\text { convection }\end{array}$} \\
\hline & & Microphysics & Convection & $\begin{array}{c}\text { Planetary } \\
\text { boundary } \\
\text { layer }\end{array}$ & $\begin{array}{c}\text { Surface } \\
\text { layer }\end{array}$ & $\begin{array}{c}\text { Land } \\
\text { surface }\end{array}$ & $\begin{array}{l}\text { Short wave } \\
\text { radiation }\end{array}$ & $\begin{array}{l}\text { Long wave } \\
\text { radiation }\end{array}$ & \\
\hline CEMPB & 526 & 4 & 3 & 1 & 1 & 2 & 3 & 1 & 30 \\
\hline CHIPB & 656 & 4 & 6 & 1 & 1 & 2 & 3 & 2 & 30 \\
\hline CHLPB & 80 & 2 & 2 & 1 & 1 & 2 & 3 & 2 & 30 \\
\hline CHSPB & 713 & 4 & 14 & 1 & 1 & 2 & 1 & 1 & 10 \\
\hline CNAPB & 157 & 2 & 3 & 1 & 2 & 2 & 3 & 1 & 10 \\
\hline CNGPB & 330 & 2 & 14 & 1 & 1 & 2 & 1 & 1 & 30 \\
\hline COAPB & 442 & 4 & 1 & 2 & 2 & 2 & 1 & 1 & 30 \\
\hline CPLPB & 681 & 4 & 6 & 2 & 1 & 2 & 1 & 1 & 10 \\
\hline СТZPB & 55 & 2 & 1 & 2 & 2 & 1 & 3 & 2 & 10 \\
\hline ECHPB & 534 & 4 & 3 & 1 & 2 & 1 & 3 & 1 & 30 \\
\hline ELCPB & 324 & 2 & 14 & 1 & 1 & 1 & 1 & 2 & 30 \\
\hline НЈТРВ & 699 & 4 & 6 & 2 & 2 & 2 & 1 & 2 & 10 \\
\hline HQCPB & 381 & 2 & 14 & 2 & 2 & 2 & 3 & 1 & 10 \\
\hline HUAPB & 242 & 2 & 5 & 2 & 2 & 1 & 1 & 1 & 30 \\
\hline IZMPB & 207 & 2 & 5 & 1 & 1 & 2 & 3 & 2 & 10 \\
\hline LIBPB & 541 & 4 & 3 & 1 & 2 & 2 & 3 & 1 & 10 \\
\hline MAYPB & 70 & 2 & 2 & 1 & 1 & 1 & 3 & 1 & 30 \\
\hline NNEPB & 45 & 2 & 1 & 2 & 1 & 2 & 3 & 1 & 10 \\
\hline OYAPB & 269 & 2 & 6 & 1 & 1 & 2 & 3 & 1 & 10 \\
\hline PCRPB & 454 & 4 & 2 & 1 & 1 & 1 & 3 & 1 & 30 \\
\hline PIXPB & 133 & 2 & 3 & 1 & 1 & 1 & 3 & 1 & 10 \\
\hline PTLPB & 410 & 4 & 1 & 1 & 2 & 2 & 1 & 1 & 30 \\
\hline PUOPB & 648 & 4 & 6 & 1 & 1 & 1 & 3 & 2 & 30 \\
\hline QUIPB & 559 & 4 & 3 & 2 & 1 & 2 & 3 & 2 & 10 \\
\hline RNAPB & 378 & 2 & 14 & 2 & 2 & 2 & 1 & 1 & 30 \\
\hline SCRPB & 717 & 4 & 14 & 1 & 1 & 2 & 3 & 1 & 10 \\
\hline SMCPB & 210 & 2 & 5 & 1 & 2 & 1 & 1 & 1 & 30 \\
\hline SOLPB & 226 & 2 & 5 & 2 & 1 & 1 & 1 & 1 & 30 \\
\hline TDRPB & 57 & 2 & 1 & 2 & 2 & 2 & 1 & 1 & 10 \\
\hline ТЕСРВ & 641 & 4 & 6 & 1 & 1 & 1 & 1 & 1 & 10 \\
\hline TEHPB & 270 & 2 & 6 & 1 & 1 & 2 & 3 & 1 & 30 \\
\hline TEOPB & 153 & 2 & 3 & 1 & 2 & 2 & 1 & 1 & 10 \\
\hline ТЕРPB & 544 & 4 & 3 & 1 & 2 & 2 & 3 & 2 & 30 \\
\hline TEZPB & 131 & 2 & 3 & 1 & 1 & 1 & 1 & 2 & 10 \\
\hline TLPPB & 59 & 2 & 1 & 2 & 2 & 2 & 1 & 2 & 10 \\
\hline TLXPB & 467 & 4 & 2 & 1 & 2 & 1 & 1 & 2 & 10 \\
\hline ТРYРB & 77 & 2 & 2 & 1 & 1 & 2 & 3 & 1 & 10 \\
\hline TYAPB & 60 & 2 & 1 & 2 & 2 & 2 & 1 & 2 & 30 \\
\hline UDSPB & 123 & 2 & 2 & 2 & 2 & 2 & 1 & 2 & 10 \\
\hline VENPB & 137 & 2 & 3 & 1 & 1 & 2 & 1 & 1 & 10 \\
\hline XDJPB & 394 & 4 & 1 & 1 & 1 & 2 & 1 & 1 & 30 \\
\hline ZCPPB & 317 & 2 & 6 & 2 & 2 & 2 & 3 & 1 & 10 \\
\hline ZOQPB & 16 & 2 & 1 & 1 & 1 & 2 & 3 & 2 & 30 \\
\hline ZRGPB & 365 & 2 & 14 & 2 & 1 & 2 & 3 & 1 & 10 \\
\hline
\end{tabular}


Table VII. Description of the optimal configuration of the WRF model by location according to the RMSE statistical parameter.

\begin{tabular}{|c|c|c|c|c|c|c|c|c|c|}
\hline \multirow[b]{2}{*}{$\begin{array}{l}\text { Station } \\
\text { key }\end{array}$} & \multirow[b]{2}{*}{$\begin{array}{l}\text { Experiment } \\
\text { number }\end{array}$} & \multicolumn{7}{|c|}{ Physical parameters } & \multirow[b]{2}{*}{$\begin{array}{l}\text { Time step } \\
\text { for the } \\
\text { convection }\end{array}$} \\
\hline & & Microphysics & Convection & $\begin{array}{c}\text { Planetary } \\
\text { boundary } \\
\text { layer }\end{array}$ & $\begin{array}{c}\text { Surface } \\
\text { layer }\end{array}$ & $\begin{array}{l}\text { Land } \\
\text { surface }\end{array}$ & $\begin{array}{c}\text { Short wave } \\
\text { radiation }\end{array}$ & $\begin{array}{l}\text { Long wave } \\
\text { radiation }\end{array}$ & \\
\hline ACHPB & 397 & 4 & 1 & 1 & 1 & 2 & 3 & 1 & 10 \\
\hline ACJPB & 398 & 4 & 1 & 1 & 1 & 2 & 3 & 1 & 30 \\
\hline ADOPB & 343 & 2 & 14 & 1 & 2 & 1 & 3 & 2 & 10 \\
\hline AFRPB & 206 & 2 & 5 & 1 & 1 & 2 & 3 & 1 & 30 \\
\hline AHAPB & 247 & 2 & 5 & 2 & 2 & 1 & 3 & 2 & 10 \\
\hline AHUPB & 622 & 4 & 5 & 2 & 1 & 2 & 3 & 1 & 30 \\
\hline APAPB & 356 & 2 & 14 & 2 & 1 & 1 & 1 & 2 & 30 \\
\hline ATXPB & 222 & 2 & 5 & 1 & 2 & 2 & 3 & 1 & 30 \\
\hline AVCPB & 141 & 2 & 3 & 1 & 1 & 2 & 3 & 1 & 10 \\
\hline CDSPB & 397 & 4 & 1 & 1 & 1 & 2 & 3 & 1 & 10 \\
\hline CEMPB & 739 & 4 & 14 & 2 & 1 & 1 & 1 & 2 & 10 \\
\hline CHIPB & 314 & 2 & 6 & 2 & 2 & 2 & 1 & 1 & 30 \\
\hline CHLPB & 718 & 4 & 14 & 1 & 1 & 2 & 3 & 1 & 30 \\
\hline CHSPB & 390 & 4 & 1 & 1 & 1 & 1 & 3 & 1 & 30 \\
\hline CNAPB & 325 & 2 & 14 & 1 & 1 & 1 & 3 & 1 & 10 \\
\hline CNGPB & 638 & 4 & 5 & 2 & 2 & 2 & 3 & 1 & 30 \\
\hline COAPB & 279 & 2 & 6 & 1 & 2 & 1 & 3 & 2 & 10 \\
\hline CPLPB & 325 & 2 & 14 & 1 & 1 & 1 & 3 & 1 & 10 \\
\hline CTZPB & 747 & 4 & 14 & 2 & 1 & 2 & 1 & 2 & 10 \\
\hline ECHPB & 214 & 2 & 5 & 1 & 2 & 1 & 3 & 1 & 30 \\
\hline ELCPB & 323 & 2 & 14 & 1 & 1 & 1 & 1 & 2 & 10 \\
\hline НJТРВ & 53 & 2 & 1 & 2 & 2 & 1 & 3 & 1 & 10 \\
\hline HQCPB & 335 & 2 & 14 & 1 & 1 & 2 & 3 & 2 & 10 \\
\hline HUAPB & 318 & 2 & 6 & 2 & 2 & 2 & 3 & 1 & 30 \\
\hline IZMPB & 718 & 4 & 14 & 1 & 1 & 2 & 3 & 1 & 30 \\
\hline LIBPB & 650 & 4 & 6 & 1 & 1 & 2 & 1 & 1 & 30 \\
\hline MAYPB & 213 & 2 & 5 & 1 & 2 & 1 & 3 & 1 & 10 \\
\hline NNEPB & 334 & 2 & 14 & 1 & 1 & 2 & 3 & 1 & 30 \\
\hline OYAPB & 314 & 2 & 6 & 2 & 2 & 2 & 1 & 1 & 30 \\
\hline PCRPB & 586 & 4 & 5 & 1 & 1 & 2 & 1 & 1 & 30 \\
\hline PIXPB & 626 & 4 & 5 & 2 & 2 & 1 & 1 & 1 & 30 \\
\hline PTLPB & 341 & 2 & 14 & 1 & 2 & 1 & 3 & 1 & 10 \\
\hline PUOPB & 610 & 4 & 5 & 2 & 1 & 1 & 1 & 1 & 30 \\
\hline QUIPB & 224 & 2 & 5 & 1 & 2 & 2 & 3 & 2 & 30 \\
\hline RNAPB & 589 & 4 & 5 & 1 & 1 & 2 & 3 & 1 & 10 \\
\hline SCRPB & 309 & 2 & 6 & 2 & 2 & 1 & 3 & 1 & 10 \\
\hline SMCPB & 470 & 4 & 2 & 1 & 2 & 1 & 3 & 1 & 30 \\
\hline SOLPB & 373 & 2 & 14 & 2 & 2 & 1 & 3 & 1 & 10 \\
\hline TDRPB & 493 & 4 & 2 & 2 & 1 & 2 & 3 & 1 & 10 \\
\hline ТЕCPB & 247 & 2 & 5 & 2 & 2 & 1 & 3 & 2 & 10 \\
\hline TEHPB & 393 & 4 & 1 & 1 & 1 & 2 & 1 & 1 & 10 \\
\hline TEOPB & 766 & 4 & 14 & 2 & 2 & 2 & 3 & 1 & 30 \\
\hline ТЕРPВ & 10 & 2 & 1 & 1 & 1 & 2 & 1 & 1 & 30 \\
\hline TEZPB & 597 & 4 & 5 & 1 & 2 & 1 & 3 & 1 & 10 \\
\hline TLPPB & 538 & 4 & 3 & 1 & 2 & 2 & 1 & 1 & 30 \\
\hline TLXPB & 725 & 4 & 14 & 1 & 2 & 1 & 3 & 1 & 10 \\
\hline TPYPB & 127 & 2 & 2 & 2 & 2 & 2 & 3 & 2 & 10 \\
\hline TYAPB & 597 & 4 & 5 & 1 & 2 & 1 & 3 & 1 & 10 \\
\hline
\end{tabular}


Table VII. Description of the optimal configuration of the WRF model by location according to the RMSE statistical parameter.

\begin{tabular}{lccccccccc}
\hline & & \multicolumn{1}{c}{ Physical parameters } & \\
\cline { 3 - 9 } $\begin{array}{l}\text { Station } \\
\text { key }\end{array}$ & $\begin{array}{c}\text { Experiment } \\
\text { number }\end{array}$ & Microphysics & Convection & $\begin{array}{c}\text { Planetary } \\
\text { boundary } \\
\text { layer }\end{array}$ & $\begin{array}{c}\text { Surface } \\
\text { layer }\end{array}$ & $\begin{array}{c}\text { Land } \\
\text { surface }\end{array}$ & $\begin{array}{c}\text { Short wave Long wave } \\
\text { radiation } \\
\text { radiation }\end{array}$ & $\begin{array}{c}\text { Time step } \\
\text { for the } \\
\text { convection }\end{array}$ \\
\hline UDSPB & 618 & 4 & 5 & 2 & 1 & 2 & 1 & 1 & 30 \\
VENPB & 621 & 4 & 5 & 2 & 1 & 2 & 1 & 2 & 30 \\
XDJPB & 670 & 4 & 6 & 1 & 2 & 2 & 3 & 1 & 30 \\
ZCPPB & 347 & 2 & 14 & 1 & 2 & 2 & 1 & 2 & 10 \\
ZOQPB & 370 & 2 & 14 & 2 & 2 & 1 & 1 & 1 & 30 \\
ZRGPB & 22 & 2 & 1 & 1 & 2 & 1 & 3 & 1 & 30 \\
\hline
\end{tabular}

Table VIII. Description of the optimal configuration of the WRF model by location according to the Pearson correlation statistical parameter.

\begin{tabular}{|c|c|c|c|c|c|c|c|c|c|}
\hline \multirow[b]{2}{*}{$\begin{array}{l}\text { Station } \\
\text { key }\end{array}$} & \multirow[b]{2}{*}{$\begin{array}{l}\text { Experiment } \\
\text { number }\end{array}$} & \multicolumn{7}{|c|}{ Physical parameters } & \multirow[b]{2}{*}{$\begin{array}{l}\text { Time step } \\
\text { for the } \\
\text { convection }\end{array}$} \\
\hline & & Microphysics & Convection & $\begin{array}{c}\text { Planetary } \\
\text { boundary } \\
\text { layer }\end{array}$ & $\begin{array}{l}\text { Surface } \\
\text { layer }\end{array}$ & $\begin{array}{l}\text { Land } \\
\text { surface }\end{array}$ & $\begin{array}{c}\text { Short wave } \\
\text { radiation }\end{array}$ & $\begin{array}{l}\text { Long wave } \\
\text { radiation }\end{array}$ & \\
\hline ACHPB & 512 & 4 & 2 & 2 & 2 & 2 & 3 & 2 & 30 \\
\hline ACJPB & 717 & 4 & 14 & 1 & 1 & 2 & 3 & 1 & 10 \\
\hline ADOPB & 343 & 2 & 14 & 1 & 2 & 1 & 3 & 2 & 10 \\
\hline AFRPB & 206 & 2 & 5 & 1 & 1 & 2 & 3 & 1 & 30 \\
\hline AHAPB & 372 & 2 & 14 & 2 & 2 & 1 & 1 & 2 & 30 \\
\hline AHUPB & 256 & 2 & 5 & 2 & 2 & 2 & 3 & 2 & 30 \\
\hline APAPB & 752 & 4 & 14 & 2 & 1 & 2 & 3 & 2 & 30 \\
\hline ATXPB & 132 & 2 & 3 & 1 & 1 & 1 & 1 & 2 & 30 \\
\hline AVCPB & 141 & 2 & 3 & 1 & 1 & 2 & 3 & 1 & 10 \\
\hline CDSPB & 636 & 4 & 5 & 2 & 2 & 2 & 1 & 2 & 30 \\
\hline CEMPB & 264 & 2 & 6 & 1 & 1 & 1 & 3 & 2 & 30 \\
\hline CHIPB & 273 & 2 & 6 & 1 & 2 & 1 & 1 & 1 & 10 \\
\hline CHLPB & 707 & 4 & 14 & 1 & 1 & 1 & 1 & 2 & 10 \\
\hline CHSPB & 1 & 2 & 1 & 1 & 1 & 1 & 1 & 1 & 10 \\
\hline CNAPB & 218 & 2 & 5 & 1 & 2 & 2 & 1 & 1 & 30 \\
\hline CNGPB & 37 & 2 & 1 & 2 & 1 & 1 & 3 & 1 & 10 \\
\hline COAPB & 279 & 2 & 6 & 1 & 2 & 1 & 3 & 2 & 10 \\
\hline CPLPB & 135 & 2 & 3 & 1 & 1 & 1 & 3 & 2 & 10 \\
\hline СТZPB & 747 & 4 & 14 & 2 & 1 & 2 & 1 & 2 & 10 \\
\hline ЕCHPB & 263 & 2 & 6 & 1 & 1 & 1 & 3 & 2 & 10 \\
\hline ELCPB & 339 & 2 & 14 & 1 & 2 & 1 & 1 & 2 & 10 \\
\hline НJТРВ & 452 & 4 & 2 & 1 & 1 & 1 & 1 & 2 & 30 \\
\hline HQCPB & 6 & 2 & 1 & 1 & 1 & 1 & 3 & 1 & 30 \\
\hline HUAPB & 277 & 2 & 6 & 1 & 2 & 1 & 3 & 1 & 10 \\
\hline IZMPB & 192 & 2 & 3 & 2 & 2 & 2 & 3 & 2 & 30 \\
\hline LIBPB & 278 & 2 & 6 & 1 & 2 & 1 & 3 & 1 & 30 \\
\hline MAYPB & 11 & 2 & 1 & 1 & 1 & 2 & 1 & 2 & 10 \\
\hline NNEPB & 140 & 2 & 3 & 1 & 1 & 2 & 1 & 2 & 30 \\
\hline OYAPB & 267 & 2 & 6 & 1 & 1 & 2 & 1 & 2 & 10 \\
\hline PCRPB & 517 & 4 & 3 & 1 & 1 & 1 & 3 & 1 & 10 \\
\hline PIXPB & 565 & 4 & 3 & 2 & 2 & 1 & 3 & 1 & 10 \\
\hline
\end{tabular}


Table VIII. Description of the optimal configuration of the WRF model by location according to the Pearson correlation statistical parameter.

\begin{tabular}{|c|c|c|c|c|c|c|c|c|c|}
\hline \multirow[b]{2}{*}{$\begin{array}{l}\text { Station } \\
\text { key }\end{array}$} & \multirow[b]{2}{*}{$\begin{array}{l}\text { Experiment } \\
\text { number }\end{array}$} & \multicolumn{7}{|c|}{ Physical parameters } & \multirow[b]{2}{*}{$\begin{array}{c}\text { Time step } \\
\text { for the } \\
\text { convection }\end{array}$} \\
\hline & & Microphysics & Convection & $\begin{array}{c}\text { Planetary } \\
\text { boundary } \\
\text { layer }\end{array}$ & $\begin{array}{c}\text { Surface } \\
\text { layer }\end{array}$ & $\begin{array}{l}\text { Land } \\
\text { surface }\end{array}$ & $\begin{array}{c}\text { Short wave } \\
\text { radiation }\end{array}$ & $\begin{array}{l}\text { Long wave } \\
\text { radiation }\end{array}$ & \\
\hline PTLPB & 341 & 2 & 14 & 1 & 2 & 1 & 3 & 1 & 10 \\
\hline PUOPB & 610 & 4 & 5 & 2 & 1 & 1 & 1 & 1 & 30 \\
\hline QUIPB & 204 & 2 & 5 & 1 & 1 & 2 & 1 & 2 & 30 \\
\hline RNAPB & 269 & 2 & 6 & 1 & 1 & 2 & 3 & 1 & 10 \\
\hline SCRPB & 21 & 2 & 1 & 1 & 2 & 1 & 3 & 1 & 10 \\
\hline SMCPB & 3 & 2 & 1 & 1 & 1 & 1 & 1 & 2 & 10 \\
\hline SOLPB & 124 & 2 & 2 & 2 & 2 & 2 & 1 & 2 & 30 \\
\hline TDRPB & 493 & 4 & 2 & 2 & 1 & 2 & 3 & 1 & 10 \\
\hline ТЕСРВ & 248 & 2 & 5 & 2 & 2 & 1 & 3 & 2 & 30 \\
\hline TEHPB & 397 & 4 & 1 & 1 & 1 & 2 & 3 & 1 & 10 \\
\hline TEOPB & 766 & 4 & 14 & 2 & 2 & 2 & 3 & 1 & 30 \\
\hline ТЕРPВ & 10 & 2 & 1 & 1 & 1 & 2 & 1 & 1 & 30 \\
\hline TEZPB & 456 & 4 & 2 & 1 & 1 & 1 & 3 & 2 & 30 \\
\hline TLPPB & 538 & 4 & 3 & 1 & 2 & 2 & 1 & 1 & 30 \\
\hline TLXPB & 725 & 4 & 14 & 1 & 2 & 1 & 3 & 1 & 10 \\
\hline ТРYРВ & 686 & 4 & 6 & 2 & 1 & 2 & 3 & 1 & 30 \\
\hline TYAPB & 259 & 2 & 6 & 1 & 1 & 1 & 1 & 2 & 10 \\
\hline UDSPB & 9 & 2 & 1 & 1 & 1 & 2 & 1 & 1 & 10 \\
\hline VENPB & 646 & 4 & 6 & 1 & 1 & 1 & 3 & 1 & 30 \\
\hline XDJPB & 670 & 4 & 6 & 1 & 2 & 2 & 3 & 1 & 30 \\
\hline ZCРPB & 752 & 4 & 14 & 2 & 1 & 2 & 3 & 2 & 30 \\
\hline ZOQPB & 328 & 2 & 14 & 1 & 1 & 1 & 3 & 2 & 30 \\
\hline ZRGPB & 394 & 4 & 1 & 1 & 1 & 2 & 1 & 1 & 30 \\
\hline
\end{tabular}

to the EMI (Table X), it was identified that the settings of the microphysics WRF Single-Moment (WSM) 5-class scheme (option 4), the convection parameterization Grell-Devenyi ensemble scheme (option 3), the planetary boundary layer parameterization Mellor-Yamada-Janjic (Eta) TKE scheme (option 2), and the long wave radiation Goddard Shortwave Scheme (option 2) are kept constant to achieve a comparable performance at the state level.

Figures 2-8 present the time series corresponding to observed precipitation in comparison to simulated precipitation by the WRF model, which were analyzed in four experiments corresponding to the following parameters: (1) less BIAS, (2) lower RMSE, (3) greater Pearson correlation, and (4) higher statewide EMI. The following four observations were derived from this time series analysis:

During the study period, the state of Puebla presented a strong rainfall concentration (greater than
$25 \mathrm{~mm}$ per day) from June 20 to July 10 . Intense to extraordinary rainfall (greater than $75 \mathrm{~mm}$ per day) also took place at 23 observation sites in the northern part of the state due to Hurricane Franklin on August 10, exceeding the highest historical rainfall at SOLPB, ZCPPB, and ZRGPB stations with records of 225, 281 and $198 \mathrm{~mm}$, respectively.

It was observed that in the CTZPB station, the observed data of extraordinary rainfall occurred on August 10 show a two-days forward displacement, while at the TEZPB station data show a one-day backward change. Therefore, there might be an error in the capture dates at these two observation sites, which would explain the poor performance of the WRF model at these locations.

Although the three best experiments identified by location (corresponding to the lower bias and RMSE, and the higher Pearson correlation) show an outstanding performance of the WRF model in 
Table IX. Statistical parameters of the 10 experiments with the best EMI at the state level.

\begin{tabular}{|c|c|c|c|c|c|c|c|c|c|c|}
\hline \multirow{2}{*}{$\begin{array}{c}\text { Experiment } \\
\text { number }\end{array}$} & \multirow[t]{2}{*}{ EMI } & \multicolumn{3}{|c|}{ BIAS } & \multicolumn{3}{|c|}{ RMSE } & \multicolumn{3}{|c|}{$\mathrm{r}$} \\
\hline & & Minimum & Maximum & Average & Minimum & Maximum & Average & Minimum & Maximum & Average \\
\hline 571 & 0.76 & -0.62 & 10.59 & 9.27 & 9.74 & 42.32 & 24.98 & 0.06 & 0.77 & 0.35 \\
\hline 555 & 0.75 & -0.23 & 10.13 & 8.46 & 9.24 & 48.36 & 24.24 & 0.05 & 0.82 & 0.34 \\
\hline 547 & 0.74 & 0.27 & 10.49 & 8.92 & 9.19 & 48.68 & 24.50 & 0.07 & 0.75 & 0.35 \\
\hline 548 & 0.74 & -0.36 & 10.70 & 9.13 & 11.22 & 46.69 & 24.83 & 0.06 & 0.79 & 0.36 \\
\hline 572 & 0.73 & -0.05 & 9.69 & 9.00 & 10.50 & 39.68 & 24.05 & 0.06 & 0.83 & 0.36 \\
\hline 551 & 0.72 & -0.23 & 11.86 & 6.66 & 9.20 & 39.10 & 22.39 & 0.07 & 0.72 & 0.37 \\
\hline 556 & 0.72 & 0.11 & 8.44 & 8.63 & 10.05 & 42.50 & 23.81 & 0.04 & 0.86 & 0.36 \\
\hline 563 & 0.71 & -0.29 & 13.73 & 6.80 & 7.66 & 37.99 & 22.43 & 0.05 & 0.82 & 0.38 \\
\hline 564 & 0.71 & -0.26 & 13.50 & 6.74 & 7.71 & 32.46 & 21.80 & 0.04 & 0.81 & 0.37 \\
\hline 552 & 0.70 & 0.97 & 11.33 & 6.83 & 10.92 & 37.73 & 21.86 & 0.08 & 0.82 & 0.39 \\
\hline
\end{tabular}

Note: experiments were ordered from highest to lowest EMI.

Table X. Parameter configuration of the cases exposed with better EMI at the state level.

\begin{tabular}{|c|c|c|c|c|c|c|c|c|}
\hline \multirow{2}{*}{$\begin{array}{l}\text { Experiment } \\
\text { number }\end{array}$} & \multicolumn{7}{|c|}{ Physical parameters } & \multirow{2}{*}{$\begin{array}{l}\text { Time step } \\
\text { for the } \\
\text { convection }\end{array}$} \\
\hline & Microphysics & Convection & $\begin{array}{c}\text { Planetary } \\
\text { boundary } \\
\text { layer }\end{array}$ & $\begin{array}{c}\text { Surface } \\
\text { layer }\end{array}$ & $\begin{array}{l}\text { Land } \\
\text { surface }\end{array}$ & $\begin{array}{l}\text { Short wave } \\
\text { radiation }\end{array}$ & $\begin{array}{l}\text { Long wave } \\
\text { radiation }\end{array}$ & \\
\hline 547 & 4 & 3 & 2 & 1 & 1 & 1 & 2 & 10 \\
\hline 548 & 4 & 3 & 2 & 1 & 1 & 1 & 2 & 30 \\
\hline 551 & 4 & 3 & 2 & 1 & 1 & 3 & 2 & 10 \\
\hline 552 & 4 & 3 & 2 & 1 & 1 & 3 & 2 & 30 \\
\hline 555 & 4 & 3 & 2 & 1 & 2 & 1 & 2 & 10 \\
\hline 556 & 4 & 3 & 2 & 1 & 2 & 1 & 2 & 30 \\
\hline 563 & 4 & 3 & 2 & 2 & 1 & 1 & 2 & 10 \\
\hline 564 & 4 & 3 & 2 & 2 & 1 & 1 & 2 & 30 \\
\hline 571 & 4 & 3 & 2 & 2 & 2 & 1 & 2 & 10 \\
\hline 572 & 4 & 3 & 2 & 2 & 2 & 1 & 2 & 30 \\
\hline
\end{tabular}

Note: The experiments correspond to those in Table IX but sorted ascendingly by experiment number for clarity.

the precipitation simulation, they do not display the same performance in a homogeneous way in the 54 observation sites.

The performance of experiment 571, with the highest EMI at the state level in the 54 observation sites, is comparable to that obtained in the experiments that presented better performance locally for the bias, RMSE and $r$ parameters.

Finally, Figure 9 shows the spatial distribution of the observed and simulated precipitation in experiment 571, together with its corresponding anomaly for August 9, 10 and 11, 2017. On day 10, the highest rainfall of the study period occurred in the northern region of the state of Puebla, associated with Hurricane Franklin. It was observed that the WRF model had the ability to simulate the intensity of precipitation during the extreme event; however, rainfall patterns show variations in detail. These variations are mainly associated with the fact that the $8-\mathrm{km}$ resolution of the model in the nested domain was insufficient to characterize the terrain in the complex topography of the state. 

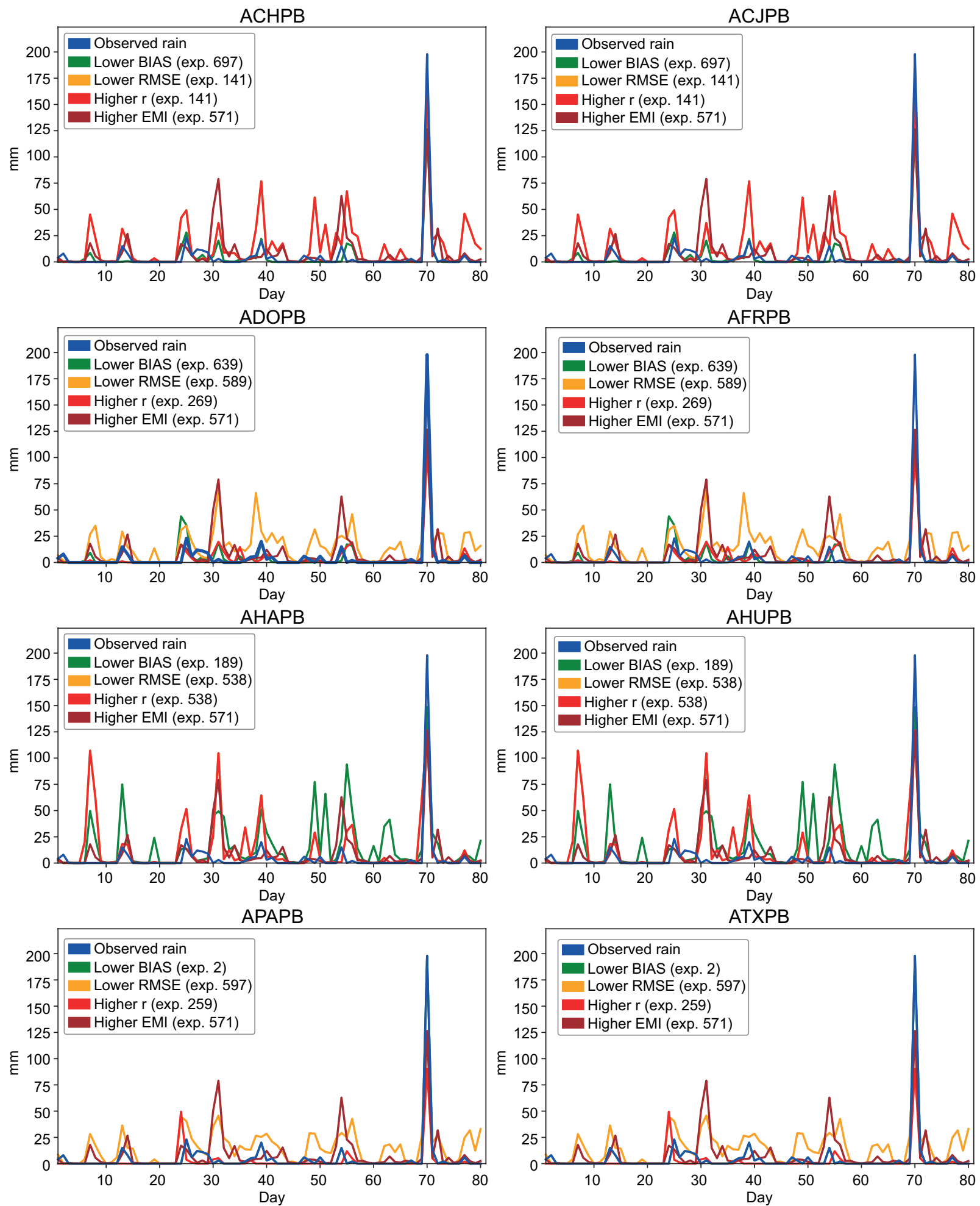

Fig. 2. Time series for the ACHPB, ACJPB, ADOPB, AFRPB, AHAPB, AHUPB, APAPB, and ATXPB stations, showing the comparison between observed precipitation and precipitation simulated by the WRF model in the four experiments with better performance in each locality. 

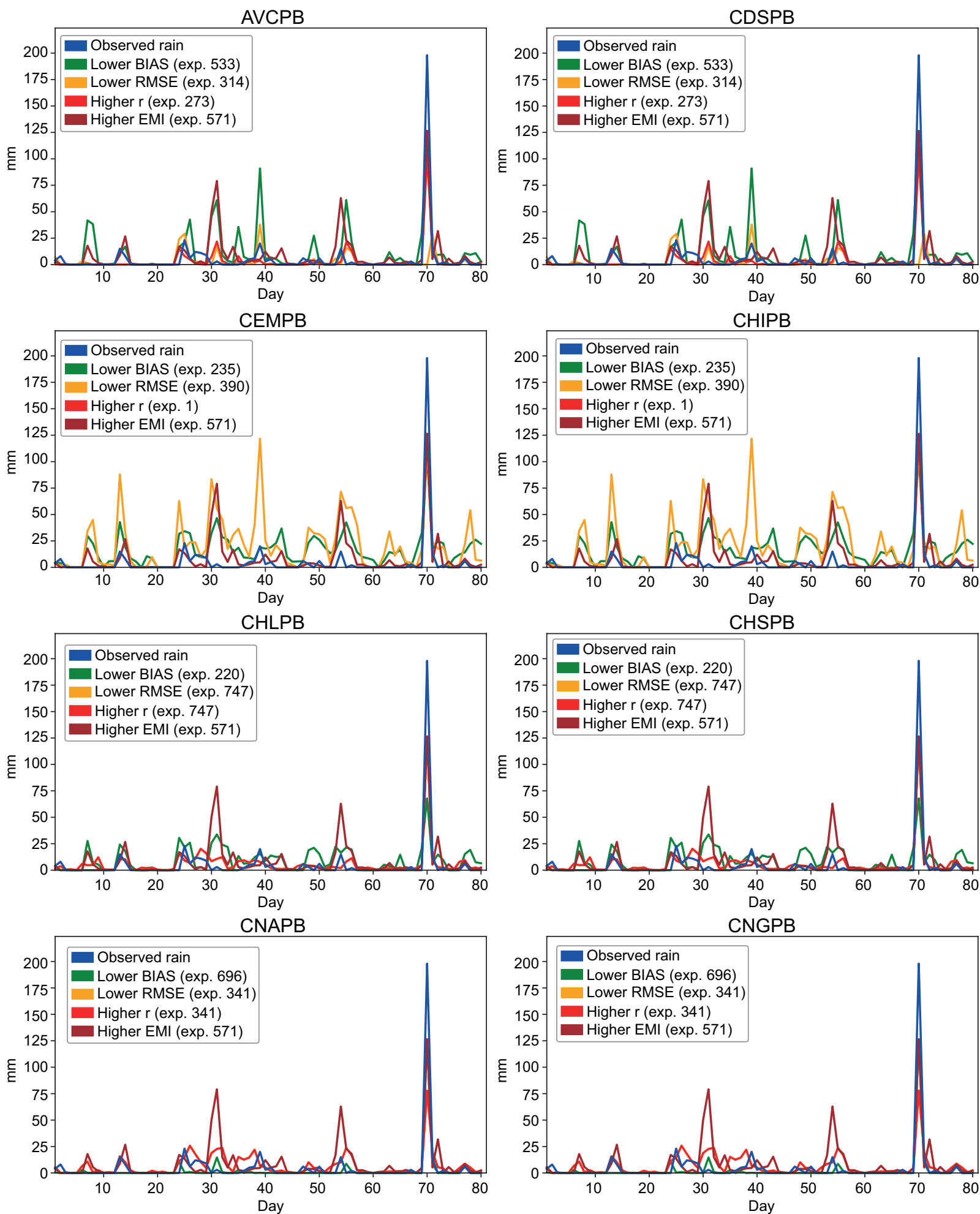

Fig. 3. Time series for the AVCPB, CDSPB, CEMPB, CHIPPB, CHLPB, CHSPB, CNAPB, and CNGPB stations, showing the comparison between observed precipitation and precipitation simulated by the WRF model in the four experiments with better performance in each locality. 

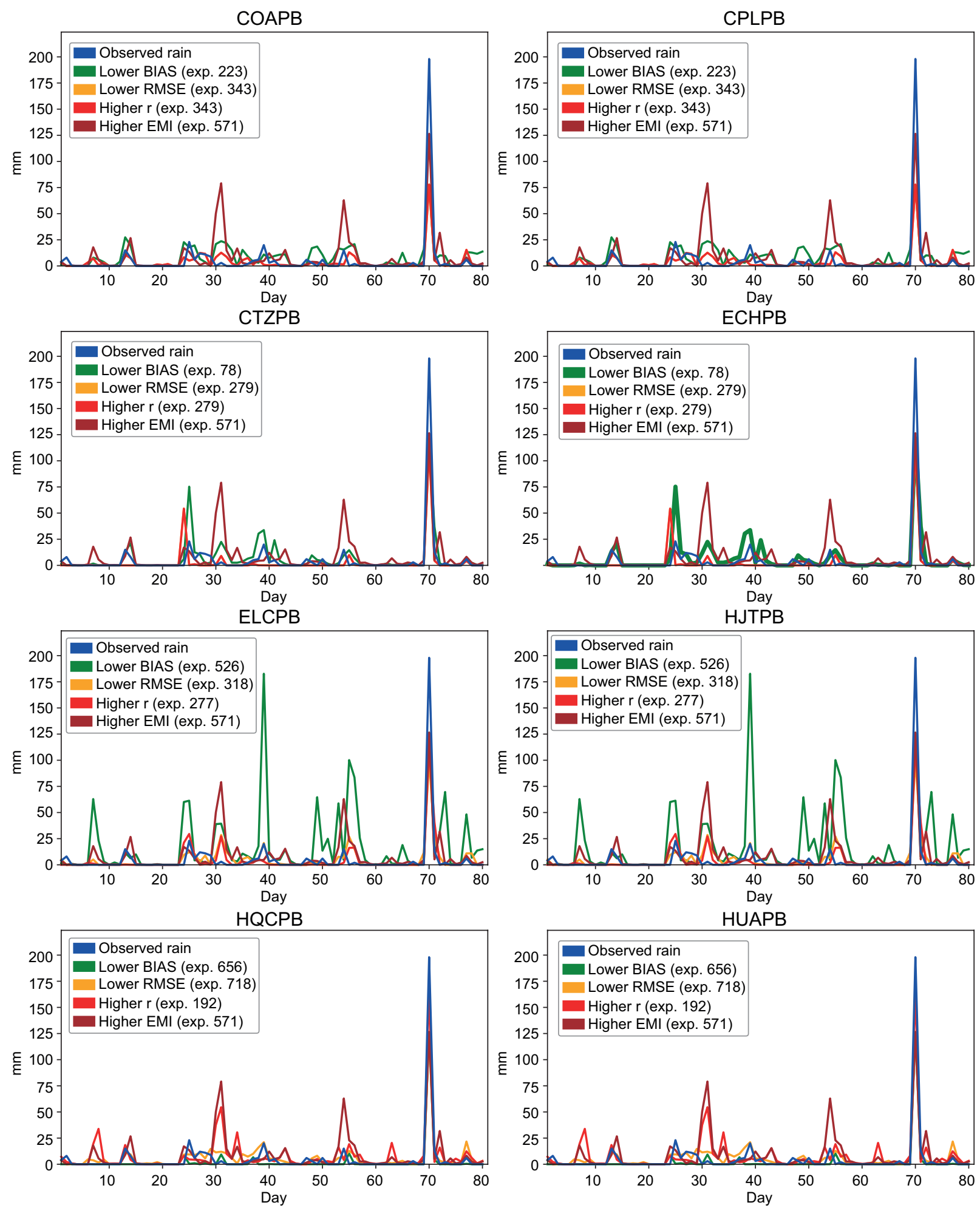

Fig. 4. Time series for the COAPB, CPLPB, CTZPB, ECHPB, ELCPB, HJTPB, HQCPB, and HUAPB stations, showing the comparison between observed precipitation and precipitation simulated by the WRF model in the four experiments with better performance in each locality. 

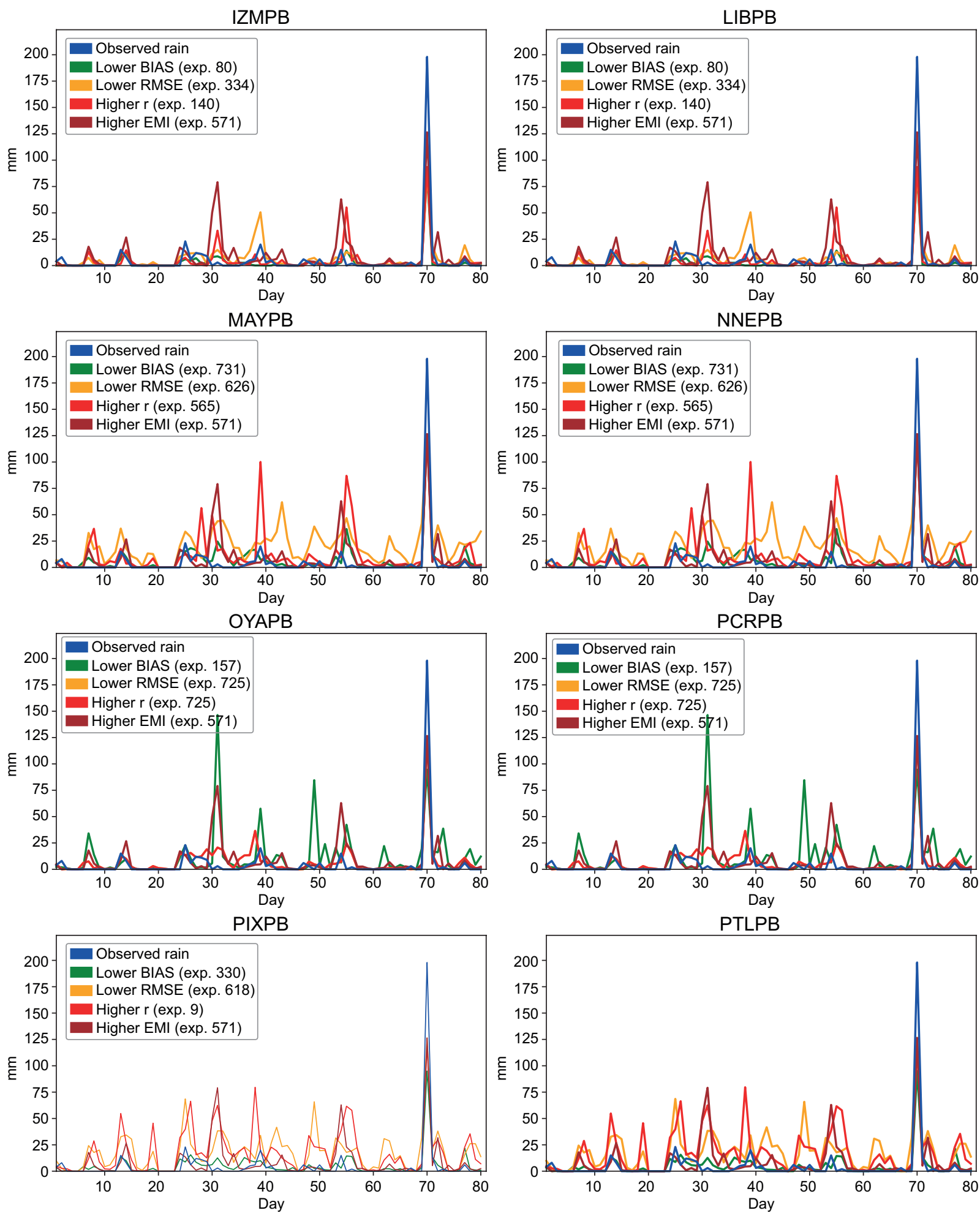

Fig. 5. Time series for the IZMPB, LIBPB, MAYPB, NNEPB, OYAPB, PCRPB, PIXPB, and PTLPB stations, showing the comparison between observed precipitation and precipitation simulated by the WRF model in the four experiments with better performance in each locality. 

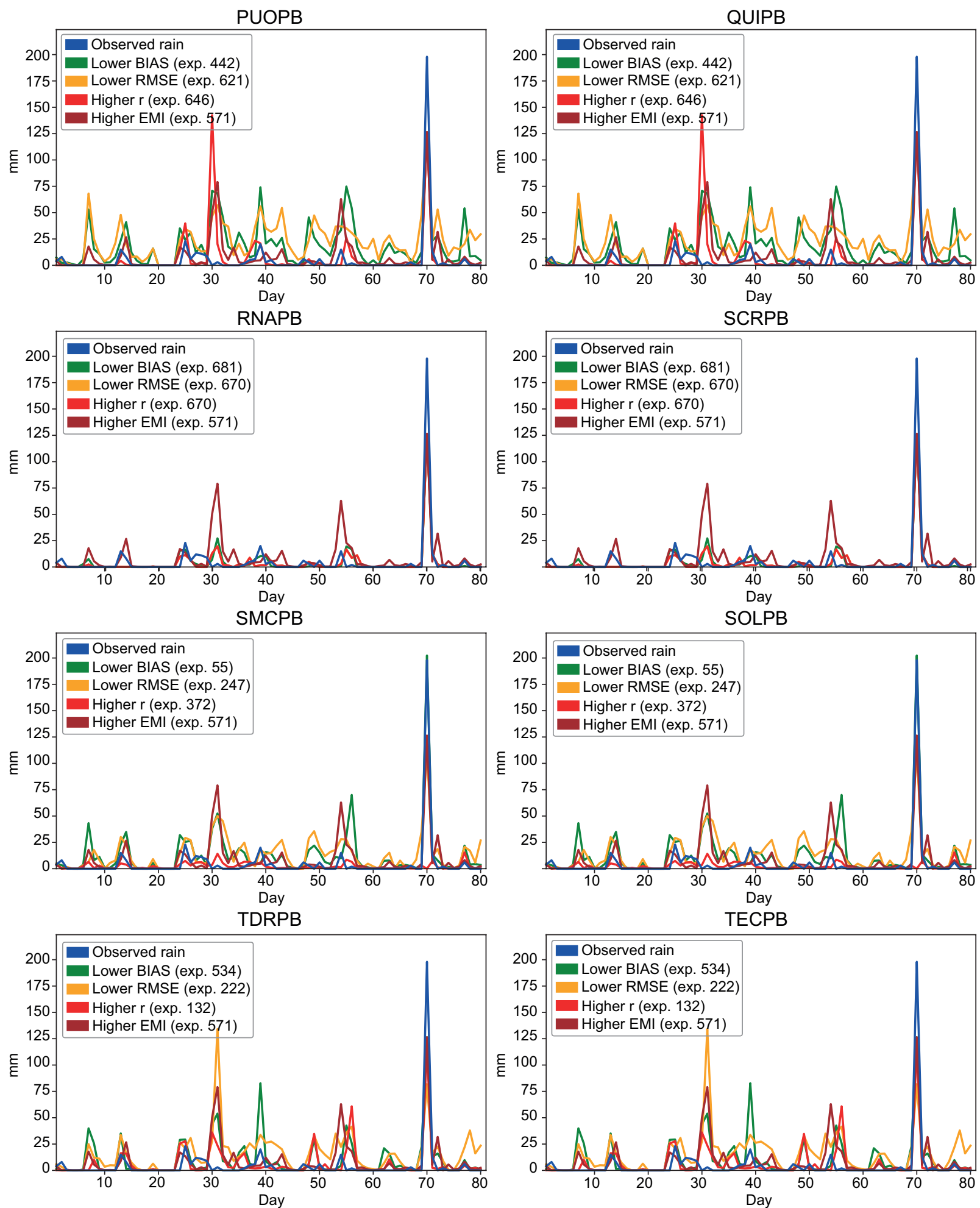

Fig. 6. Time series for the PUOPB, QUIPB, RNAPB, SCRPB, SMCPB, SOLPB, TDRPB, and TECPB stations, showing the comparison between observed precipitation and precipitation simulated by the WRF model in the four experiments with better performance in each locality. 

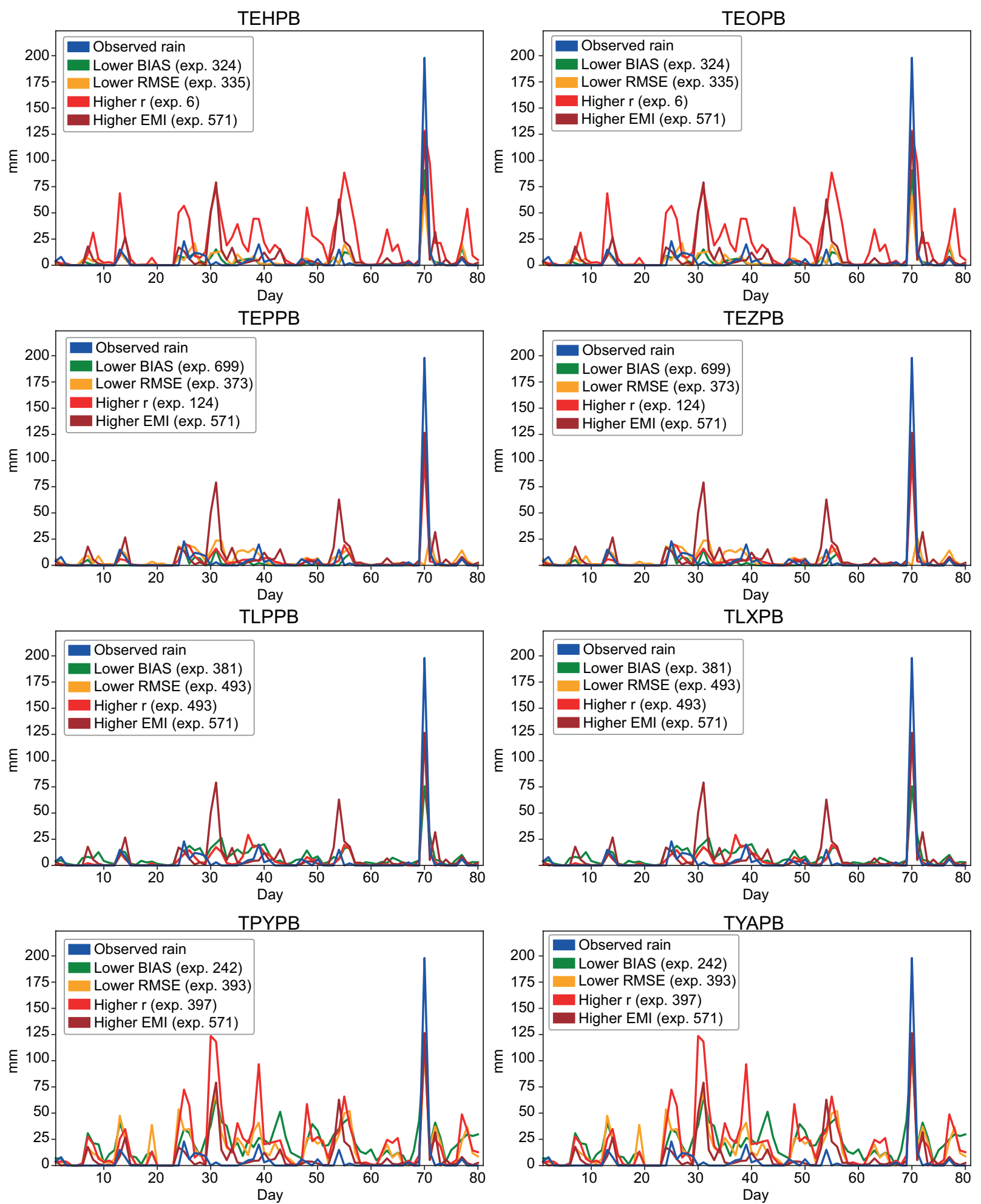

Fig. 7. Time series for the TEHPB, TEOPB, TEPPB, TEZPB, TLPPB, TLXPB, TPYPB, and TYAPB stations, showing the comparison between observed precipitation and precipitation simulated by the WRF model in the four experiments with better performance in each locality. 
TEHPB

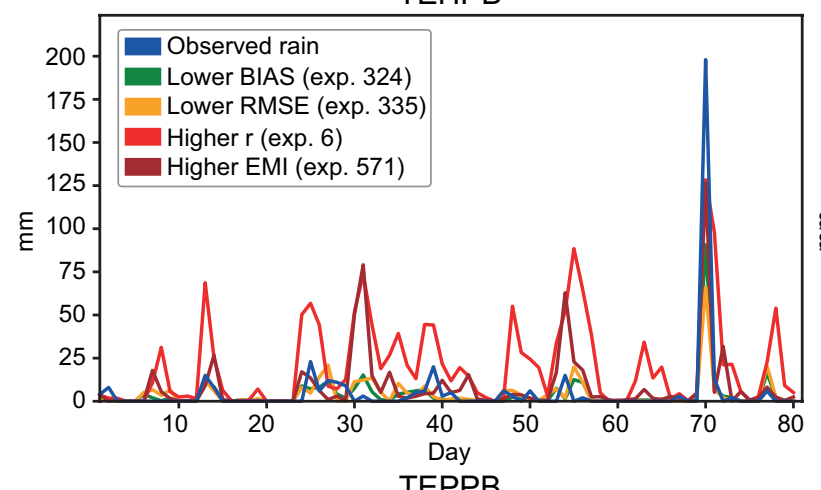

TEPPB

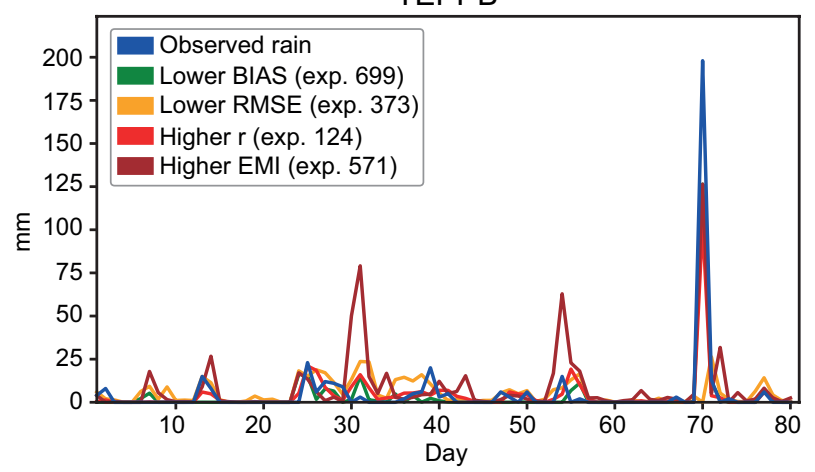

TLPPB

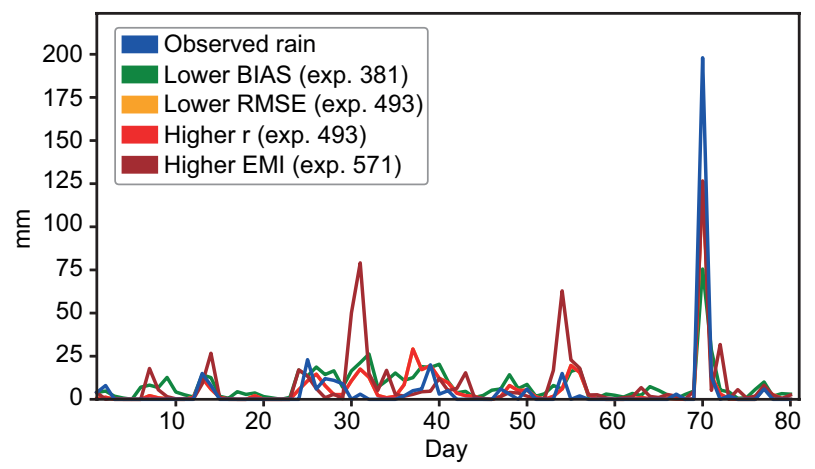

TEOPB

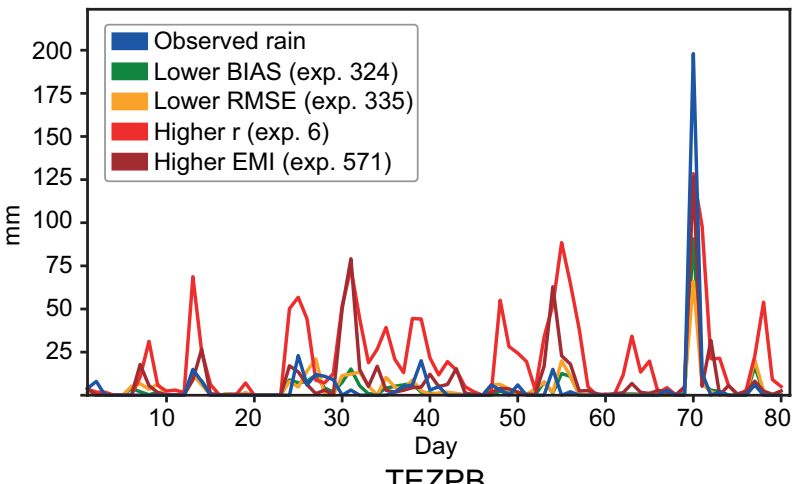

TEZPB

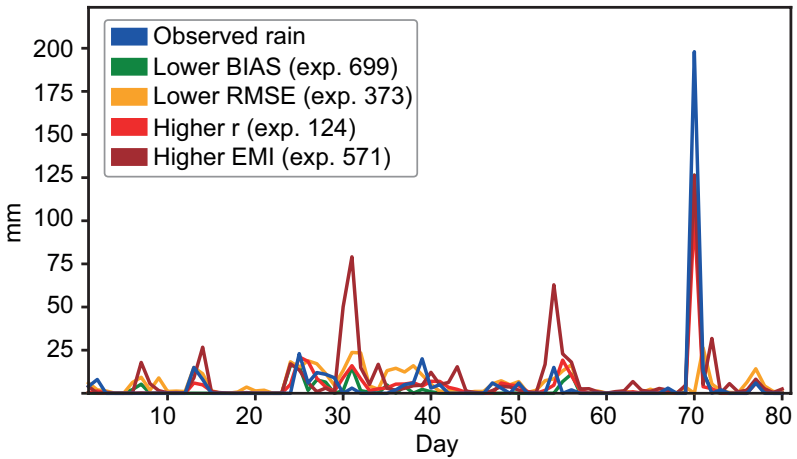

TLXPB

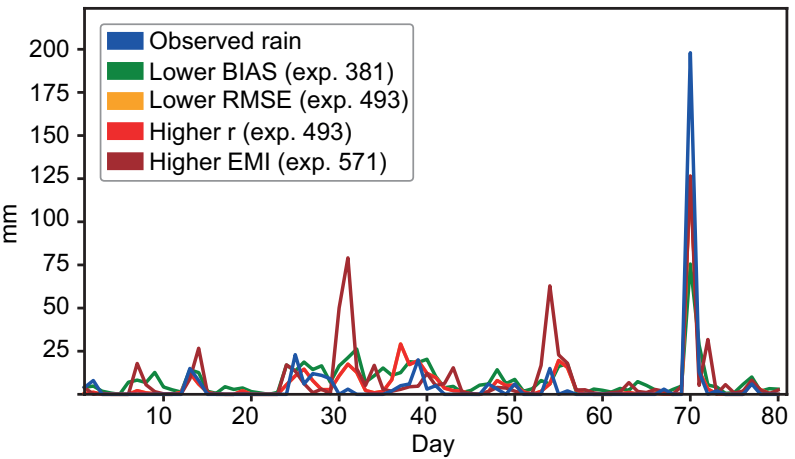

Fig. 8. Time series for the UDSPB, VENPB, XDJPB, ZCPPB, ZOQPB, and ZRGPB stations, showing the comparison between observed precipitation and precipitation simulated by the WRF model in the four experiments with better performance in each locality.

\section{Discussion}

The performance of the mesoscale models is sensitive to physical parameterization schemes, so it is necessary to perform several experiments with different combinations (Das et al., 2015). In this context, the relevance of evaluating the WRF model with different physical settings for the state of Puebla is evident, especially before the possible implementation of the model in an operational way for the issuance of mete- orological alerts, the implementation of early warning systems, or the undertaking of studies. Otherwise there is a risk of obtaining values that do not represent the real or approximate precipitation behavior, and significant errors in the forecast will hinder the prevention and analysis of natural disasters.

In correspondence with the works of Ochoa et al. (2015) and Wu et al. (2016), it is highlighted that the WRF model can reproduce individual peaks of 

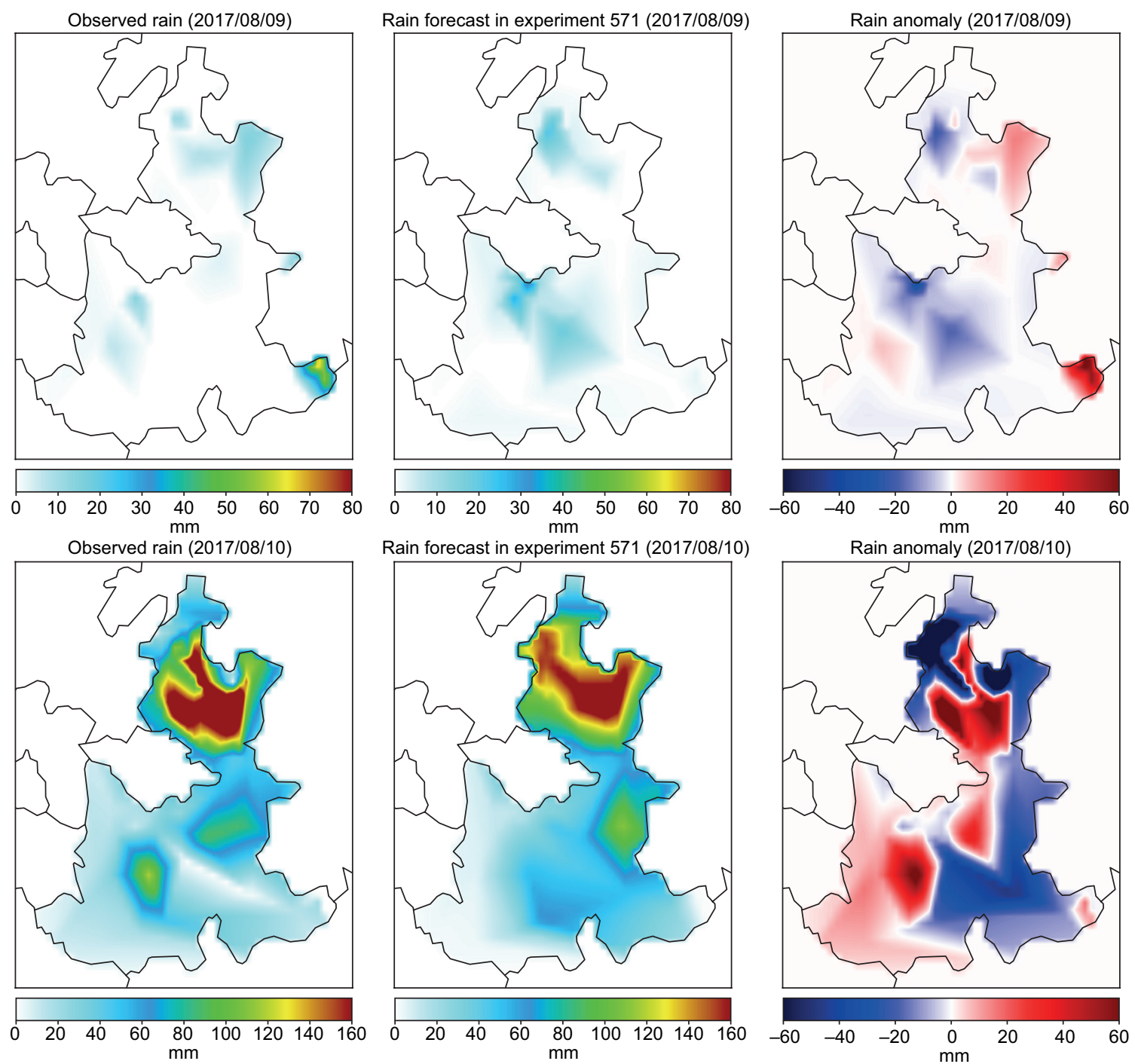

Rain forecast in experiment $571(2017 / 08 / 10)$
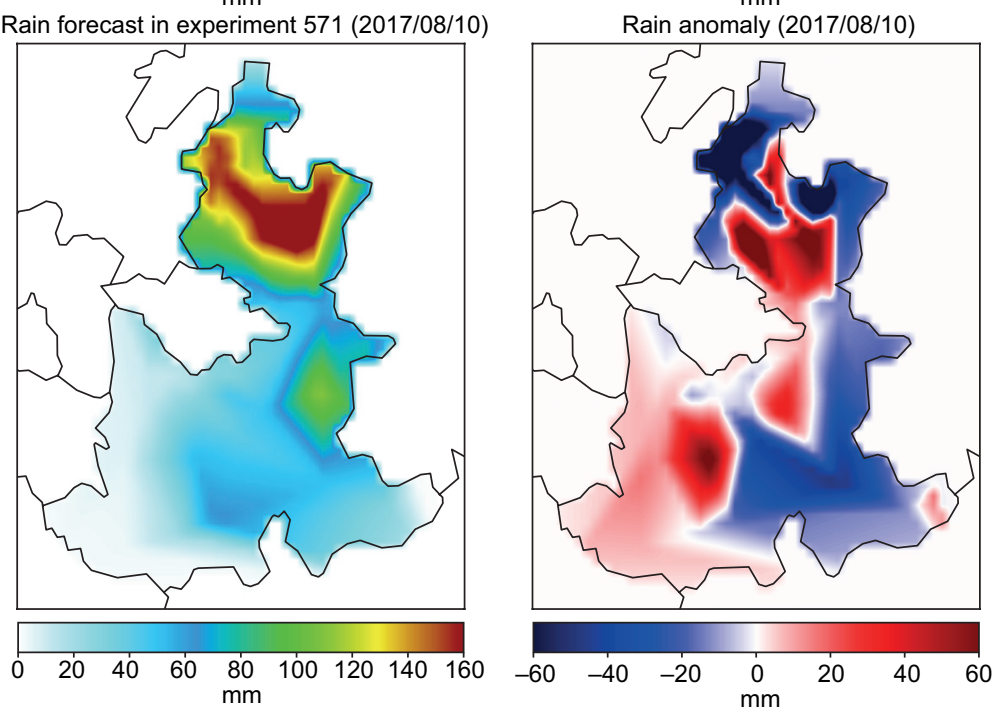

Rain forecast in experiment $571(2017 / 08 / 11)$
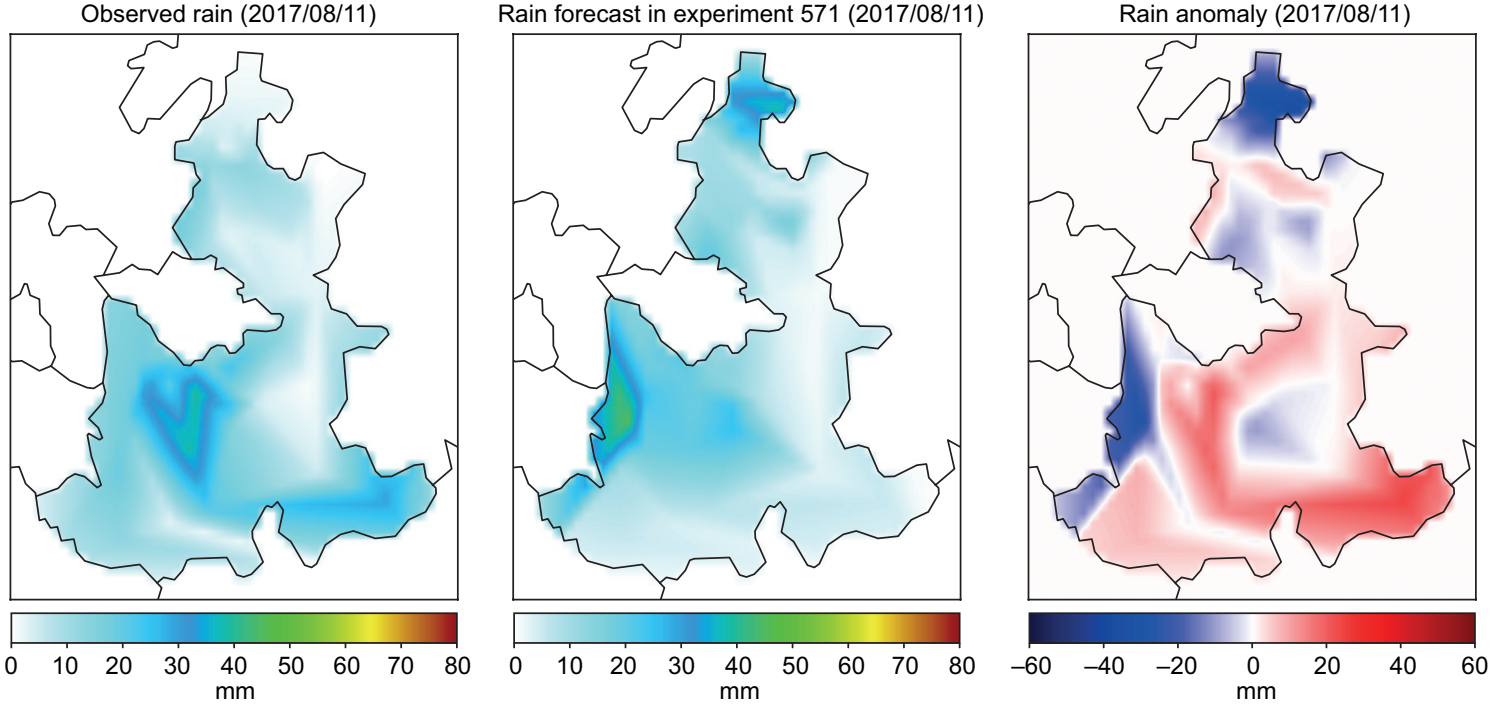

Fig. 9. Spatial distribution of rainfall on August 9-11, 2017. Left: observed rainfall; center: rainfall simulated with the WRF model in experiment 571; right: anomaly between observed rainfall and rainfall simulated in experiment 571. 
precipitation, thus allowing to analyze the evolution of intense precipitation events in the study area, such as those observed on August 10 in the north region of the state of Puebla, originated by the passage of Hurricane Franklin. On the other hand, Lekhadiya and Jana (2018) mention that the WRF model can very well represent the cloud pattern and spatially recognizes rain events, but that it overestimates the determination in the six parameterization schemes evaluated in their study.

The results in this study point out that the WRF model has the capacity to achieve a high performance for precipitation forecast in specific locations in the state of Puebla, attaining very high positive correlations with values of up to 0.98 at the OYAPB, ZCPPB, and ZRGPB stations, a limited significant cumulative bias of \pm 0.01 in 41 of the observation sites $(76 \%)$, and a low intensity RMSE with values below $3.18 \mathrm{~mm}$ at ACHPB and TPYPB stations. However, the optimal configuration of the model in one location does not offer the same level of performance in other observation sites. This result corresponds to Jankov and Gallus (2005), who evaluated the impact of 18 different combinations of physical settings and their interaction with the precipitation of mesoscale convective systems, concluding that none of the scores obtained with the evaluation metrics applied (correspondence relationship and squared correlation coefficient) in the 18 combinations was the best for all times and thresholds. However, in this study, by selecting experiment 571 , which obtained the highest EMI value, it was shown that it is possible to obtain acceptable results at the state level.

\section{Conclusions}

In compliance with the first objective of this work, the results of the quantitative evaluation of the WRF model performance for simulating rainfall in the state of Puebla, allowed us to determine that it is possible to configure the model to obtain high performance per observation site and acceptable performance statewide.

Of the 54 observation sites, only the TEZPB station had unsatisfactory results with respect to the Pearson correlation, which obtained a maximum of 0.06 in experiment 456, and a high RMSE with a value of 25.54 in experiment 597. However, for this location, an acceptable bias was obtained with a value of -0.01 in experiment 131 .

The application of the Efficiency Multiparameter Index allowed the determination of experiment 571 as the optimal configuration of the WRF model for a statewide application. In addition, after analyzing the 10 best configurations according to the EMI, it was identified that the settings of the microphysics WRF Single-Moment (WSM) 5-class scheme (option 4), the convection parameterization Grell-Devenyi ensemble scheme (option 3), the planetary boundary layer parameterization Mellor-Yamada-Janjic (Eta) TKE scheme (option 2), and the long wave radiation Goddard Shortwave Scheme (option 2), should remain constant to achieve acceptable and uniform performance at the state level.

It should benoted that, in general, the WRF model has a better performance at altitudes greater than 2000 masl, especially in the northern and central regions of the state of Puebla, while in latitudes below 1000 masl, mainly in the south and southeast regions of the state, the model performance is below the state average.

The social relevance of this study lies in the fact that the northwest region of the state of Puebla presents a high risk of flooding due to the rainfall characteristics of the area and the occurrence of tropical cyclones. During the study period, the rainfall reported on August 10 due to the occurrence of Hurricane Franklin exceeded the historical maximum according to official CONAGUA records, with values of 225, 281 and $198 \mathrm{~mm}$ at SOLPB, ZCPPB, and Zaragoza ZRGPB stations, respectively. For this same day, the rainfall simulated with the WRF model reached values of $198 / 187 / 208 / 196$ at the SOLPB station, 207/245/226/201 at the ZCPPB station, and $126 / 106 / 126 / 126$ at the ZRGPB station in the four best cases exposed by location, that is, the cases with lower BIAS and RMSE, and higher $r$ and EMI at the state level. These results indicate that running the WRF model with the optimal configuration will allow to anticipate the magnitude of precipitation events in the state of Puebla with a high degree of precision. Also, with the intervention of an experienced weather forecaster, it is possible to obtain reliable precipitation forecast advisories and bulletins. This will allow authorities, companies and citizens to mitigate or even prevent catastrophic damage caused by extraordinary precipitation. 
Additionally, the differentiated signal between bias and RMSE in the best experiments for each observation site, indicates that in the simulation of precipitation in the state of Puebla, the WRF model does not present systematic errors that can be adjusted directly by linear regression. That is, the errors occur randomly, associated with the chaotic behavior of the atmosphere.

Finally, as future work, it is proposed to apply the methodology presented in this research to calibrate the WRF model at the national level.

\section{References}

Aguilar C. 1997. Simulación de sistemas, aplicaciones en producción animal. Colección en Agricultura. Pontificia Universidad Católica de Chile, Facultad de Agronomía, Santiago, Chile.

Anderson DR, Sweeney DJ, Williams TA. 2008. Estadística para administración y economía. 10a ed. Cengage Learning, México, 1056 p.

Arreguín-Cortés FI, López-Pérez M, Rodríguez-López O, Montero-Martínez MJ (coords.). 2015. Atlas de vulnerabilidad hídrica en México ante el cambio climático: efectos del cambio climático en el recurso hídrico de México. Instituto Mexicano de Tecnología del Agua, Jiutepec, México.

Aparicio J. 1998. Inundaciones: la otra cara de la moneda. Revista Tláloc, órgano informativo de la Asociación Mexicana de Hidráulica 5(11), 15-20.

Babbie ER. 2014. The basics of social research. Wadsworth Cengage Learning, Belmont, CA.

Barrales L, Peña I, Fernández P. 2004. Validación de modelos: un enfoque aplicado. Agricultura Técnica 64(1), 66-73.

Benjamin MA. 2008. Analysing urban flood risk in lowcost settlements of George, Western Cape, South Africa: Investigating physical and social dimensions. M.Sc. Thesis. University of Cape Town, Cape Town, South Africa.

Campbell DT, Stanley JC. 2012. Diseños experimentales y cuasiexperimentales en la investigación social. 2a ed. Amorrortu, España.

Carbonell Turtos L, Capote Mastrapa G, Fonseca Rodríguez Y, Álvarez Escudero L, Sánchez Gacita M, Bezanilla Morlot A, Borrajero Montejo I, Meneses Ruiz E, Pire Rivas S. 2003. Assessment of the Weather Research and Forecasting model implementation in Cuba addressed to diagnostic air quality modeling.
Atmospheric Pollution Research 4, 64-74. https://doi. org/10.5094/APR.2013.007

CONAGUA. 2017. Las lluvias que dejó \#Franklin rompieron récords históricos en \#Puebla. Comisión Nacional del Agua, 10 de agosto [tuit]. Available at: https://twitter.com/conagua_clima/status/895776809563734017

Creswell JW. 2013. Research design: Qualitative, quantitative, and mixed methods. Sage Publications, USA.

Das MK, Chowdhury AM, Das S. 2015. Sensitivity study with physical parameterization schemes for simulation of mesoscale convective systems associated with squall events. International Journal of Earth and Atmospheric Science 2, 20-36.

Douben KJ. 2006. Characteristics of river floods and flooding: A global overview, 1983-2003. Irrigation and Drainage 55, 9-21. https://doi.org/ https://doi. org/10.1002/ird.239

Gavidia M. 2012. Simulación de las variables meteorológicas en la ciudad de Lima para el verano e invierno de 2009 con el modelo Weather Research and Forecasting. Bachelor thesis in Environmental Engineering. Universidad Nacional Agraria La Molina, Lima, Perú.

Henríquez-Fierro E, Zepeda-González MI. 2003. Preparación de un proyecto de investigación. Ciencia y Enfermería 9, 23-28. https://doi.org/10.4067/S071795532003000200003

Hernández-Sampeiri R, Fernández-Collado C, Baptista-Lucio P. 2014. Metodología de la investigación. 6a ed. McGrawHill, México.

Hernández-Uribe RE, Barrios-Piña H, Ramírez AI. 2017. Análisis de riesgo por inundación: metodología y aplicación a la cuenca Atemajac. Tecnología y Ciencias del Agua 8, 5-25. https://doi.org/10.24850/j-tyca-2017-03-01

Jankov I, Gallus WA. 2005. The impact of different WRF model physical parameterizations and their interactions on warm season MCS rainfall. Weather and Forecasting 20, 1048-1060. https://doi.org/10.1175/WAF888.1

Jáuregui E. 1989. Los ciclones del norte de México y sus efectos sobre la precipitación. Ingeniería Hidráulica en México, septiembre-diciembre.

Kalnay E. 2003. Atmospheric modeling, data assimilation, and predictability. Cambridge University Press, New York, USA.

Lekhadiya HS, Jana RK. 2018. Analysis of extreme rainfall event with different microphysics and parameterization schemes in WRF model. Positioning 9, 1-11. https:// doi.org/10.4236/pos.2018.91001 
Mitchell PL. 1997. Misuse of regression for empirical validation of models. Agricultural Systems 54, 313326. https://doi.org/10.1016/S0308-521X(96)00077-7

Mondragón-Barrera MA. 2014. Uso de la correlación de Spearman en un estudio de intervención en fisioterapia. Movimiento científico 8(1), 98-104. https://doi. org/10.33881/2011-7191.mct.08111

Moya-Álvarez AS, Ortega-León JM. 2015. Aplicación del modelo meteorológico WRF para el pronóstico de precipitaciones en período lluvioso de Cuba, 2014. Apuntes de Ciencia \& Sociedad 5, 135-145. https:// doi.org/10.18259/acs.2015021

Moya de Madrigal L. 2005. Introducción a la estadística de la salud. 6a ed. Universidad de Costa Rica, Costa Rica, 330 pp.

Ochoa CA, Quintanar AI, Raga GB, Baumgardner D. 2015. Changes in intense precipitation events in Mexico City. Journal of Hydrometeorology 16, 1804-1820. https:// doi.org/10.1175/JHM-D-14-0081.1

Pielke RA. 1984. Mesoscale meteorological modeling. Academic Press, Orlando, FL.

Rauscher HM, Young MJ, Webb CD, Rohison DJ. 2000. Testing the accuracy of growth and yields models for Southern hardwood forests. Southern Journal of Applied Forestry 24(3), 176-185.

Reynolds MR. 1984. Estimating the error in model predictions. Forest Science 30, 454-469. https://doi. org/10.1093/forestscience/30.2.454

SEGOB. 2009. Características e impacto socioeconómico de los principales desastres ocurridos en la República
Mexicana en el año 2008. Centro Nacional de Prevención de Desastres, Secretaria de Gobernación, México.

Skamarock WC, Klemp JB, Dudhia J, Gill DO, Barker DM, Huang X-Y, Wang W, Powers JG. 2008. Description of the Advanced Research WRF version 3. National Center for Atmospheric Research, Boulder, Colorado, USA. https://doi.org/10.5065/ D68S4MVH

Tamayo JL. 1996. Geografía moderna de México. Trillas, México.

White TL, McBurney DH. 2013. Research methods. Cengage Learning, USA, 458 pp.

Wu D, Peters-Lidard C, Tao WK, Petersen W. 2016. Evaluation of NU-WRF rainfall forecasts for IFloodS. Journal of Hidrometeorology 17, 1317-1335. https:/ doi.org/10.1175/JHM-D-15-0134.1

Zepka GS. 2011. Previsão de descargas atmosféricas usando o modelo de mesoescala WRF. Ph.D. Thesis in Space Geophysics. Instituto Nacional de Pesquisas Espaciais, São José dos Campos, Brasil.

Willmott CJ. 1982. Some comments on the evaluation of model performance. Bulletin of the American Meteorological Society 63, 1309-1313. https://doi.org/10.1 175/1520-0477(1982)063<1309:SCOTEO >2.0.CO;2

Willmott C, Ackleson S, Davis R, Feddema J, Klink K, Legates D, O’Donnell J, Rowe C. 1985. Statistics for the evaluation and comparison of models. Journal of Geophysical Research: Oceans 90. https://doi. org/10.1029/JC090iC05p08995 